Supporting Information for:

\title{
Understanding the Roles of Triethylaluminum in Phosphinimide- Supported Titanium Catalyst Systems for Ethylene Polymerization
}

Jared L. Barr, ${ }^{\dagger}$ Amit Kumar, ${ }^{+, \#}$ Davide Lionetti,,,$\#$ Carlos A. Cruz, ${ }^{* \dagger}$ and James D. Blakemore ${ }^{*,+, \#}$

$\dagger$ Phillips 66 Research Center, Chevron Phillips Chemical Company LP, Bartlesville, Oklahoma 74003, United States

$\$$ Department of Chemistry, University of Kansas, 1567 Irving Hill Road, Lawrence, Kansas 66045, United States

\# Center for Environmentally Beneficial Catalysis, University of Kansas, 1501 Wakarusa Drive, Lawrence, Kansas 66047, United States

To whom correspondence should be addressed: cruzca@cpchem.com (C.A.C.);

blakemore@ku.edu (J.D.B.)

\section{Contents}

General Experimental Details $\quad$ S3

Synthesis of $1 \quad$ S5

Synthesis of 2

NMR Spectra

Figure S1. ${ }^{1} \mathrm{H}$ NMR spectrum of Phosphinimine $\quad$ S6

Figure S2. ${ }^{13} \mathrm{P}\left\{{ }^{1} \mathrm{H}\right\}$ NMR spectrum of Phosphinimine $\quad$ S6

Figure S3. ${ }^{1} \mathrm{H}$ NMR spectrum of $\mathbf{1} \quad$ S7

Figure S4. ${ }^{13} \mathrm{P}\left\{{ }^{1} \mathrm{H}\right\}$ NMR spectrum of $\mathbf{1} \quad$ S7

Figure S5. ${ }^{1} \mathrm{H}$ NMR spectrum of $\mathbf{2} \quad$ S8

Figure S6. ${ }^{13} \mathrm{P}\left\{{ }^{1} \mathrm{H}\right\}$ NMR spectrum of $\mathbf{2} \quad$ S8

\section{UV-Vis Spectra}

Figure S7. Stacked UV/Vis spectra of $\mathbf{1}$ and $\mathbf{2} \quad$ S9

Figure S8. UV/Vis spectra of $\mathbf{2}$ in various solvents $\quad$ S9

\section{Electrochemistry}

Figure S9. Cyclic Voltammetry (CV) Data for AlEt 3 in THF $\quad$ S10

Figure S10. CV Data for 4 in the absence and presence of Cobaltocene in THF $\quad$ S10

Figure S11. CV Data for 4 in the absence and presence of Cobaltocene in THF $\quad$ S11

Figure S12. CV Data for 1 in the presence of Cobaltocene in THF S11

Figure S13. Stacked CVs for $\mathbf{1}$ and $\mathbf{1}$ in the presence of AlEt ${ }_{3}$ in THF $\quad \mathrm{S} 12$

Figure S14. Scan rate dependence (SRD) of $\mathbf{1}$ and $\mathbf{1}$ in the presence of AlEt ${ }_{3}$ in THF S13

Figure S15. Linear Dependence of Peak Current on Square Root of Scan Rate $\quad$ S14

Figure S16. Electrochemical titration of 1 in the presence of AlEt ${ }_{3}$ in THF 


\section{Spectroelectrochemistry}

Figure S17. Spectroelectrochemical Data of 1 in the presence of $\mathrm{AlEt}_{3}$ in THF

Gas Chromatography

Figure S18. Gas Chromatography Data during Chemical Reduction of 1

Figure S19. Gas Chromatography Data during Bulk Electrolysis of $\mathbf{1}$

\section{EPR Spectra}

Figure S20. Electron paramagnetic resonance spectrum of $\mathbf{2}$ in various solvents

Figure S21. Electron paramagnetic resonance spectrum of $\mathbf{2}$ in toluene with modeling

\section{Mechanistic Pathway}

Figure S22. Electrochemical Pathway for the formation of $\mathbf{2}$ from $\mathbf{1}$

X-Ray Crystallography

Table S1. Crystal and Refinement Data for 1 and 2

Table S2. Comparison of Select Bond Lengths $(\AA)$

Table S3. Comparison of Select Bond Angles $\left({ }^{\circ}\right)$. 


\section{General Experimental Details}

All manipulations were carried out in dry $\mathrm{N}_{2}$-filled gloveboxes (Vacuum Atmospheres Co., Hawthorne, CA) or under $\mathrm{N}_{2}$ atmosphere using standard Schlenk techniques unless otherwise noted. Ethylene was obtained from Airgas and was further purified through columns of $13 \mathrm{X}$ molecular sieves. 1-Hexene was obtained from Chevron Phillips Chemical Company LP and dried over A-201 type activated alumina. All solvents were of commercial grade and dried over activated alumina using a Pure Process Technology (PPT; Nashua, $\mathrm{NH})$ solvent purification system prior to use, and were stored over molecular sieves or anhydrous solvents were purchased from Sigma-Aldrich and purified and stored over 13X molecular sieves. Benzene- $\mathrm{d}_{6}$ was purchased from Cambridge Isotope Labs, dried and stored over 13X molecular sieves. ${ }^{1} \mathrm{H}$ and ${ }^{31} \mathrm{P}$ NMR spectra were collected on 400 and $500 \mathrm{MHz}$ Bruker spectrometers and referenced to the residual protio-solvent signal in the case of ${ }^{1} \mathrm{H}$ and to the deuterium lock signal in the case of ${ }^{31} \mathrm{P}$ unless otherwise noted. Triethylaluminum ( $1 \mathrm{M}$ solution in hexane or $0.6 \mathrm{M}$ solution in heptane), $t \mathrm{Bu}_{3} \mathrm{P}$ and trimethylsilylazide were purchased from Sigma-Aldrich or Acros Organics and used as received. [(Ind) $\mathrm{TiCl}_{3}$ ] was purchased from Strem Chemicals and used as received. 1 and the solid super acid activator were prepared according to literature methods.,2,3 All chemicals were from major commercial suppliers and used after extensive drying.

Electrochemical experiments were carried out in a $\mathrm{N}_{2}$-filled glovebox in dry, degassed THF. $0.10 \mathrm{M}$ tetra(n-butylammonium) hexafluorophosphate $\left(\left[\mathrm{nBu}_{4} \mathrm{~N}\right]^{+}\left[\mathrm{PF}_{6}\right]^{-}\right)$; Sigma-Aldrich, electrochemical grade) served as the supporting electrolyte. Measurements were made with a Gamry Reference 600+ Potentiostat/Galvanostat using a standard three-electrode configuration. The working electrode was the basal plane of highly oriented pyrolytic graphite (HOPG) (GraphiteStore.com, Buffalo Grove, Ill.; surface area: $0.09 \mathrm{~cm}^{2}$ ), the counter electrode was a platinum wire (Kurt J. Lesker, Jefferson Hills, PA; 99.99\%, 0.5 mm diameter), and a silver wire immersed in electrolyte served as a pseudoreference electrode (CH Instruments). The reference was separated from the working solution by a Vycor frit (Bioanalytical Systems, Inc.). Ferrocene (Sigma Aldrich; twice-sublimed) was added to the solution after each experiment; the midpoint potential of the ferrocenium/ferrocene couple (denoted as $\mathrm{Fc}^{+/ 0}$ ) served as an internal standard for comparison of the recorded potentials. Concentrations of analyte for cyclic voltammetry were ca. 1 to $2 \mathrm{mM}$ unless otherwise noted.

Electronic absorption spectra were collected with an Ocean Optics Flame spectrometer, in a 1-cm path length quartz cuvette.

Spectroelectrochemisty was carried out in the same glovebox as described above $\left(\mathrm{N}_{2}\right.$ atmosphere), with $0.10 \mathrm{M}\left[\mathrm{nBu}_{4} \mathrm{~N}^{+}\left[\mathrm{PF}_{6}\right]^{-}\right.$in THF as electrolyte. A thin layer quartz cell was used with a Teflon cap for housing the electrodes (ALS Co., Ltd., path length: $1.0 \mathrm{~mm}$ ). The working electrode was a platinum mesh/flag electrode covered with a PTFE shrink tube up 
to the flag, and the counter and reference electrodes were both platinum wires (ALS Co., Ltd.).

Gas analysis for determination of gas evolution was performed with a Shimadzu GC-2014 Custom-GC gas chromatograph with a thermal conductivity detector and dual flameionization detectors. A custom set of eight columns and timed valves enable quantitative analysis of hydrogen, nitrogen, oxygen, carbon dioxide, carbon monoxide, methane, ethane, ethylene, and ethyne. Argon serves as the carrier gas. The instrument was calibrated with a standard checkout gas mixture (Agilent 5190-0519) prior to experimental runs to obtain quantitative data for ethylene.

Bulk electrolysis experiments were performed in a custom two-chamber electrochemical cell equipped with connections to achieve gas-tight operation. The working electrode was an HOPG plate (Graphitestore.com, Buffalo Grove, Ill.; surface area: $10 \mathrm{~cm}^{2}$ ).

\section{Bench Polymerization Experiments}

Polymerizations were performed on a $2.2 \mathrm{~L}$ stainless steel reactor equipped with a marine stirrer rotating at $500 \mathrm{rpm}$. The reactor was surrounded by a stainless-steel jacket through which a stream of hot water was circulated, which permitted precise temperature control to within half a degree centigrade. Prior to polymerization, the reactor was purged at $110-$ $120^{\circ} \mathrm{C}$ with nitrogen for at least 30 minutes. The reactor was then cooled and charged with $0.1 \mathrm{~g}$ of solid superacid, $0.5 \mathrm{~mL}$ of triethylaluminum ( $1 \mathrm{M}$ in hexane, $0.5 \mathrm{mmol}$ ), and 0.001 $\mathrm{g}$ of 1 as a $1 \mathrm{mg} / \mathrm{mL}$ solution of catalyst in toluene, and filled with $1.2 \mathrm{~L}$ of isobutane liquid, in that order, under a stream of isobutane vapors at $45^{\circ} \mathrm{C}$. Finally, ethylene was added to the reactor to equal the desired pressure, which was maintained during the experiment. 1-hexene $(10 \mathrm{~g})$ was pumped directly into the reactor from a weighed storage vessel upon initiation of the polymerization experiment. Hydrogen was metered in to the reactor along with the ethylene to a prescribed $125 \mathrm{ppm}$ level. After the allotted reaction time, the ethylene flow was stopped, and the reactor was slowly depressurized and opened to recover the granular polymer powder. The reactor was clean with no indication of any wall scale, coating or other forms of fouling. The polymer powder was then removed and weighed, and the activity was determined from this weight and the measured time based on the amount of catalyst charged.

\section{Melt Index Determination}

Approximately $7 \mathrm{~g}$ of polymer was loaded into the barrel of a Tinius Olsen EP600 extrusion plastometer melt flow apparatus that was preheated to $190^{\circ} \mathrm{C}$. After a 6-minute melting time, a $2.16 \mathrm{~kg}$ weight (melt index) was automatically loaded onto the plunger to force the molten polyethylene through a circular die. The distance travelled by the weight and time are measured and used to calculate melt index in $\mathrm{dg} \mathrm{min}^{-1}$. Following melt flow determination, 
additional weights to produce a total of $21.6 \mathrm{~kg}$ (high load melt index) was automatically loaded onto the plunger to force the molten polyethylene through the circular die. The distance travelled by the weight and time are measured and used to calculate a high load melt index in $\mathrm{dg} \mathrm{min}^{-1}$.

\section{SEC Measurements}

Molecular weights and molecular weight distributions were obtained using a Polymer Labs (now an Agilent company) PL-220 gel permeation chromatograph with 1,2,4-trichlorobenzene as the solvent at a flow rate of $1 \mathrm{~mL} / \mathrm{min}$ and at $145^{\circ} \mathrm{C}$. 2,6-di-tert-butyl-4-methylphenol (BHT) at a concentration of $0.5 \mathrm{~g} / \mathrm{L}$ was used as a stabilizer in the solvent. An injection volume of $400 \mu \mathrm{L}$ was used with a nominal polymer concentration of $1 \mathrm{~g} / \mathrm{L}$. Dissolution of the stabilized sample was carried out by heating at $150^{\circ} \mathrm{C}$ for $5 \mathrm{~h}$ with occasional agitation. Three Waters HT-6E columns $(7.8 \times 300 \mathrm{~mm})$ were used and calibrated with a broad linear polyethylene standard (Phillips Marlex ${ }^{\circledR}$ BHB 5003) whose molecular weight had previously been determined.

\section{Synthesis of 1}

1 was prepared according to Stephan and co-workers. ${ }^{1}{ }^{1} \mathrm{H}$ NMR spectra collected for the synthesized material were in accord with prior results. Elemental analysis confirmed preparation of the desired material. Anal. Calc'd for $\mathrm{C}_{21} \mathrm{H}_{34} \mathrm{Cl}_{2} \mathrm{NPTi}$ : C, 56.02; H, 7.61, N, 3.11. Found: C, $55.85 ; \mathrm{H}, 7.42, \mathrm{~N}, 3.23$.

\section{Synthesis of 2}

In the glovebox under an inert atmosphere of nitrogen, a $20 \mathrm{~mL}$ scintillation vial was loaded with $1(100 \mathrm{mg}, 0.222 \mathrm{mmol})$ and suspended in $10 \mathrm{~mL}$ pentane or benzene. Using a syringe, 2 equiv. of $0.6 \mathrm{M}$ solution of triethylaluminum ( $\left.\mathrm{AlEt}_{3}\right)$ in heptane $(0.7 \mathrm{~mL}, 0.444 \mathrm{mmol})$ was added dropwise to this yellowish green color suspension or solution respectively, over a period of 15 minutes. The color of the solution changed from yellowish green to emerald green within half an hour of addition. The resultant homogenous solution was stirred for another hour and concentrated. This viscous liquid was then refrigerated at $-35^{\circ} \mathrm{C}$ to give deep emerald green crystals of $\mathbf{2}$. Satisfactory elemental analysis results for $\mathbf{2}$ were not obtained despite several attempts, likely due to the acute sensitivity of this compound to air and moisture. 


\section{NMR Spectra}

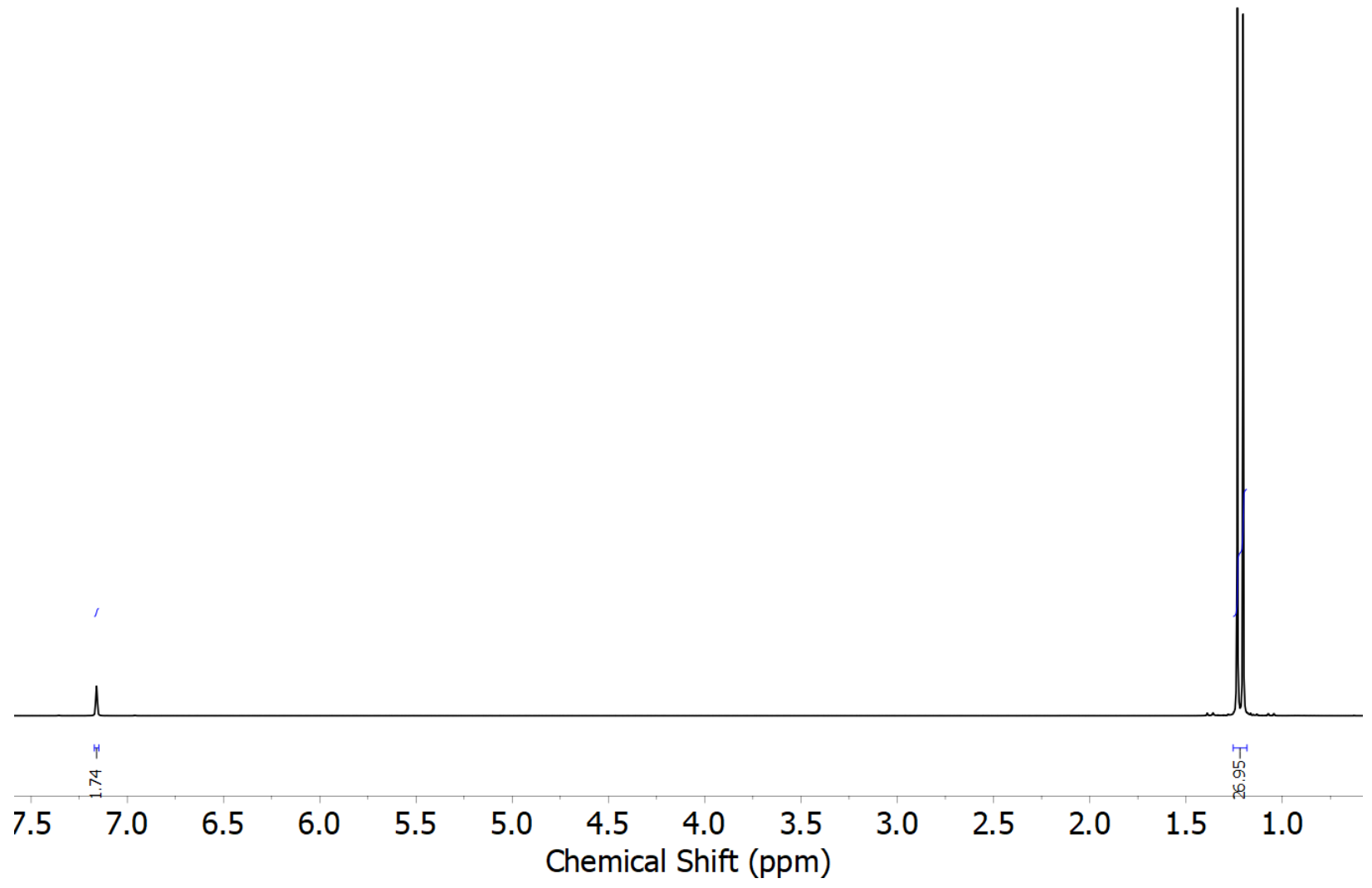

Figure S1. ${ }^{1} \mathrm{H}$ NMR spectrum $\left(400 \mathrm{MHz}, \mathrm{C}_{6} \mathrm{D}_{6}\right)$ of Phosphinimine.

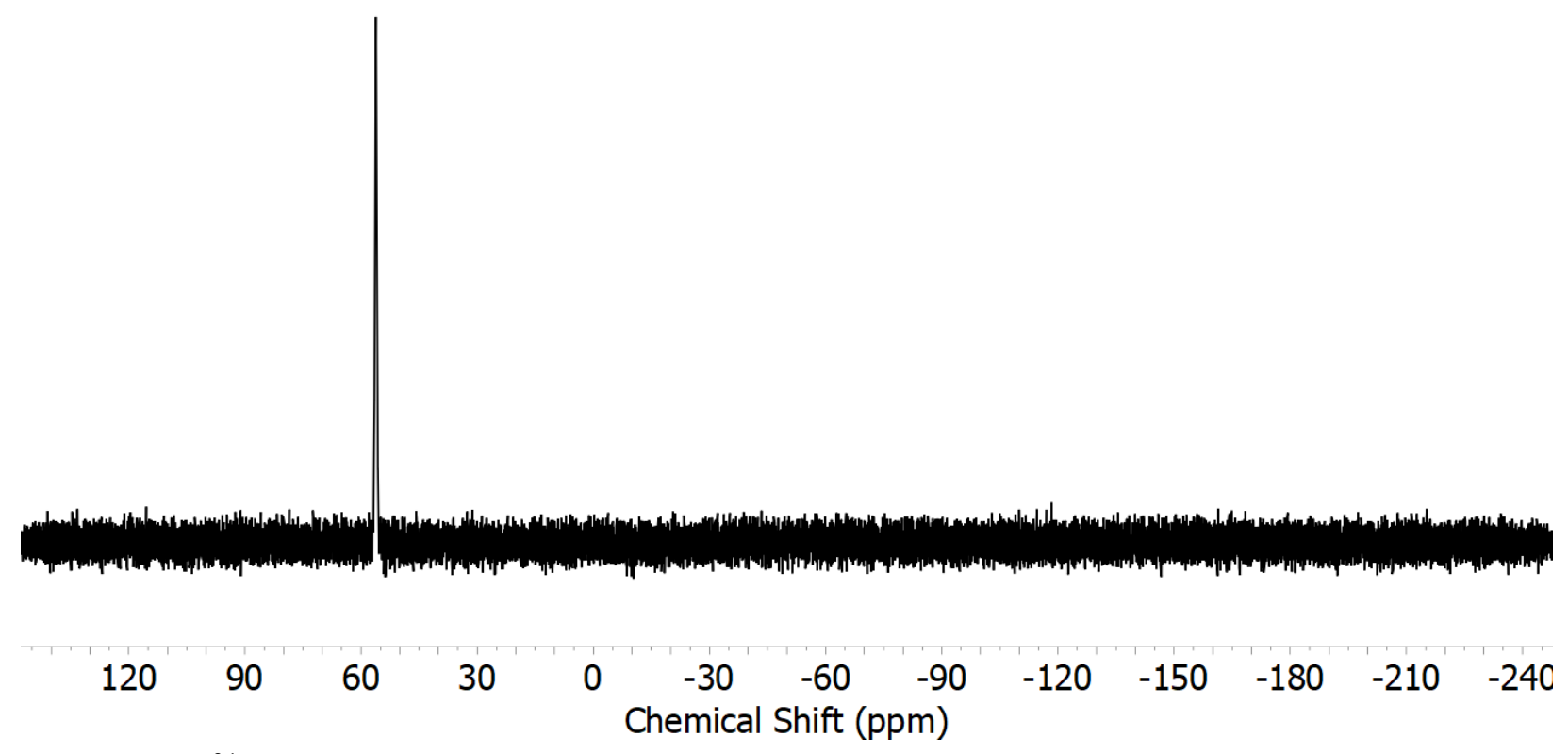

Figure S2. ${ }^{31} \mathrm{P}$ NMR spectrum $\left(162 \mathrm{MHz}, \mathrm{C}_{6} \mathrm{D}_{6}\right)$ of Phosphinimine. 


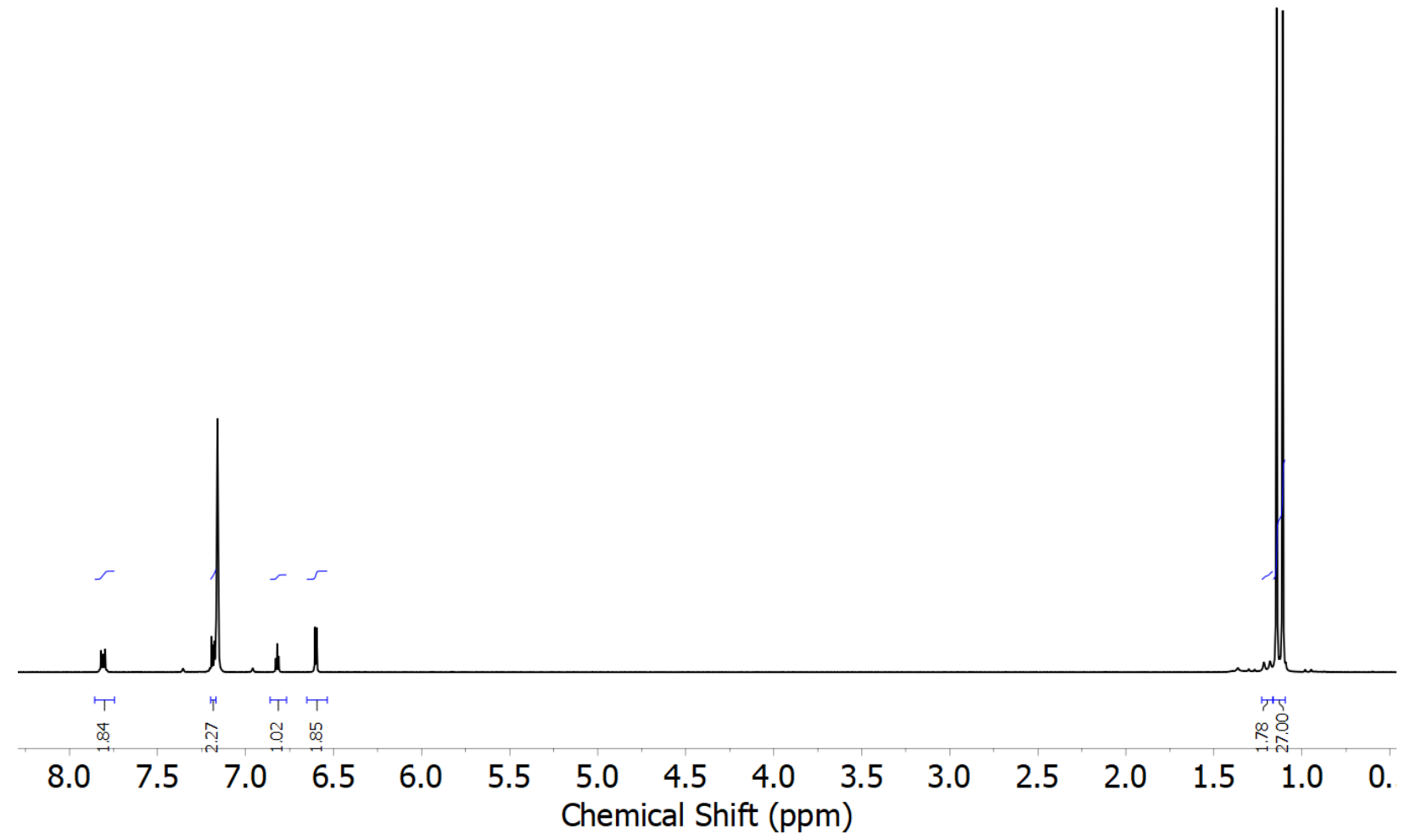

Figure S3. ${ }^{1} \mathrm{H}$ NMR spectrum $\left(400 \mathrm{MHz}, \mathrm{C}_{6} \mathrm{D}_{6}\right)$ of $\mathbf{1}$.

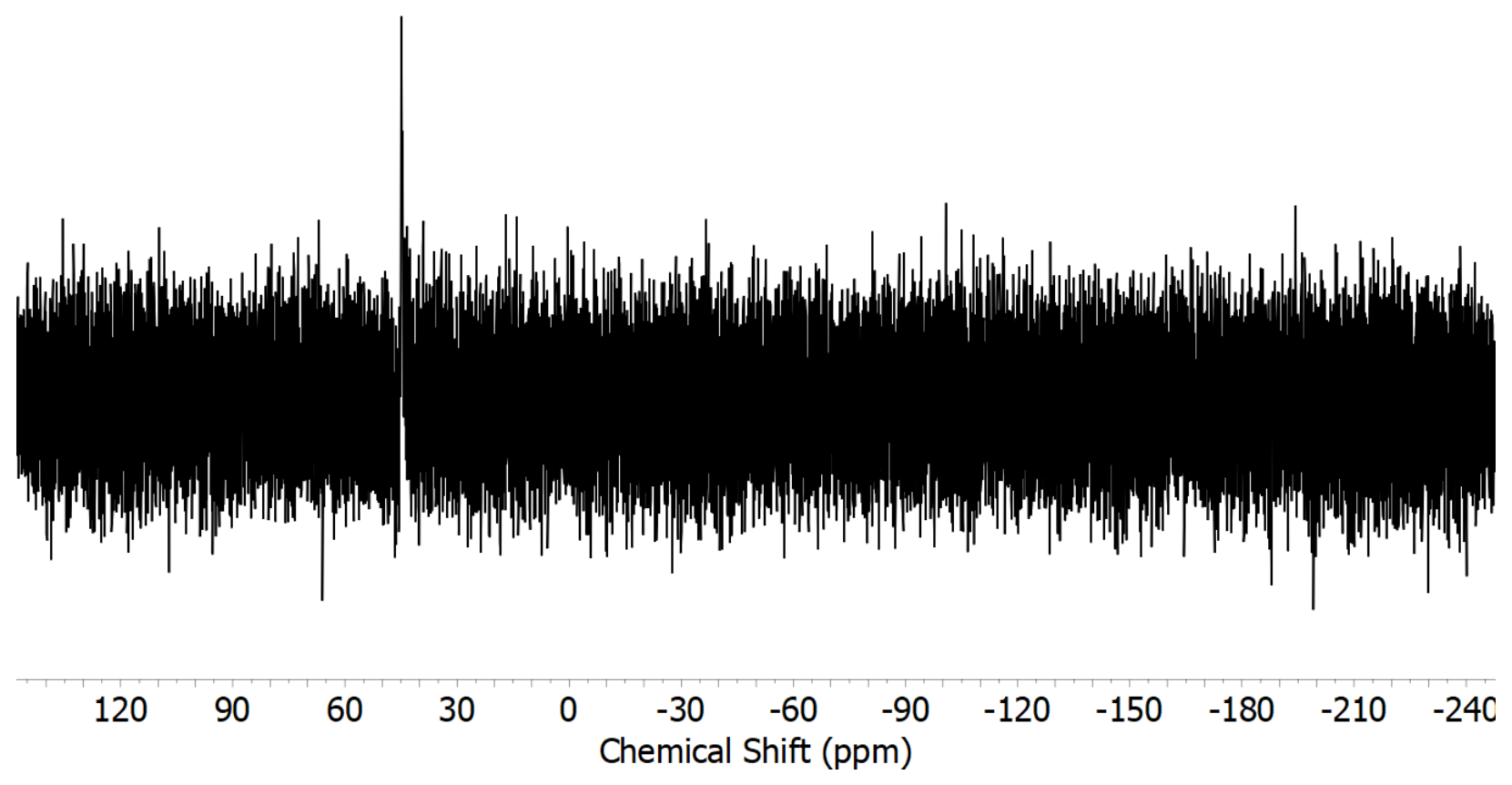

Figure S4. ${ }^{31} \mathrm{P}$ NMR spectrum $\left(162 \mathrm{MHz}, \mathrm{C}_{6} \mathrm{D}_{6}\right)$ of $\mathbf{1}$. 


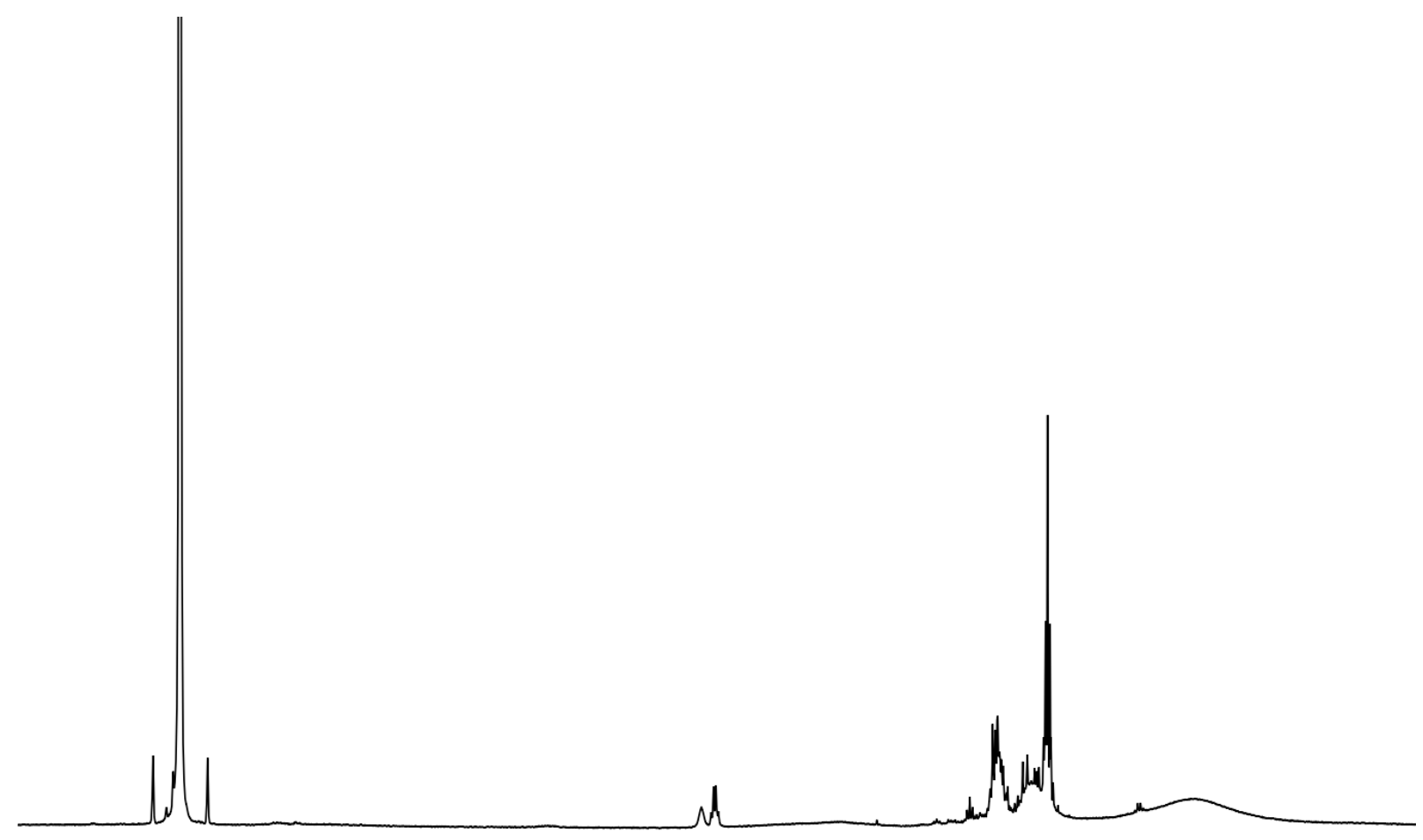

\section{$\begin{array}{llllllllllllllllllllll}8.0 & 7.5 & 7.0 & 6.5 & 6.0 & 5.5 & 5.0 & 4.5 & 4.0 & 3.5 & 3.0 & 2.5 & 2.0 & 1.5 & 1.0 & 0.5 & 0.0 & -0.5 & -1.0 & -1.5\end{array}$ Chemical Shift (ppm)}

Figure S5. ${ }^{1} \mathrm{H}$ NMR spectrum $\left(400 \mathrm{MHz}, \mathrm{C}_{6} \mathrm{D}_{6}\right)$ of 2.

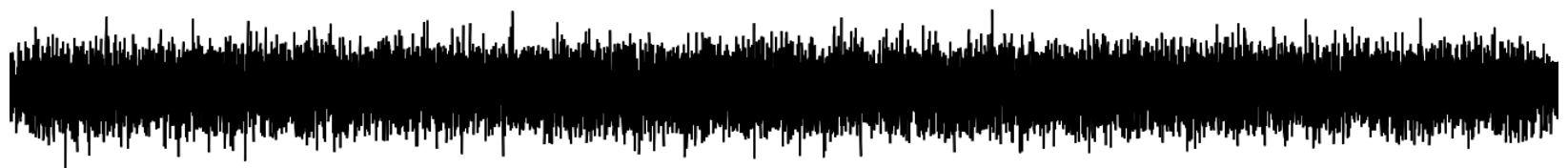

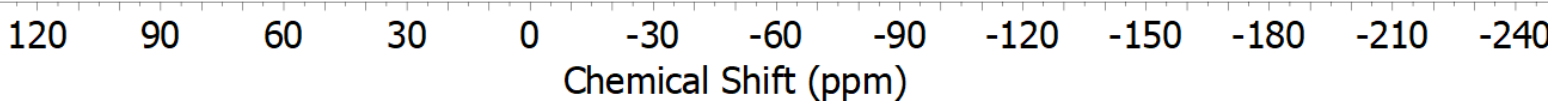

Figure S6. ${ }^{31} \mathrm{P}$ NMR spectrum $\left(162 \mathrm{MHz}, \mathrm{C}_{6} \mathrm{D}_{6}\right)$ of 2. 


\section{Electronic Absorption Spectra}

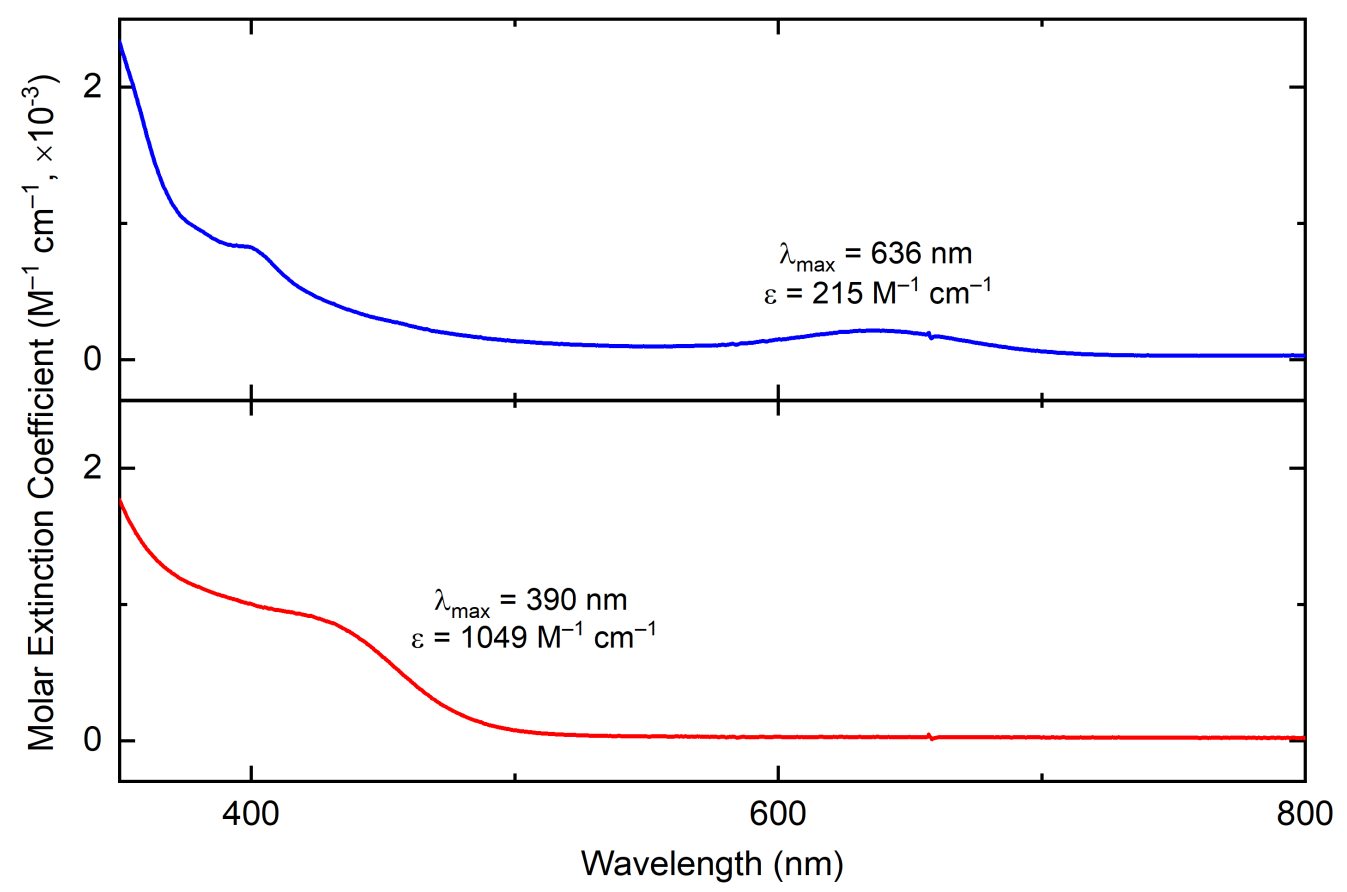

Figure S7. Stacked Electronic absorption spectra of 2 (blue) and 1 (red) in pentane.

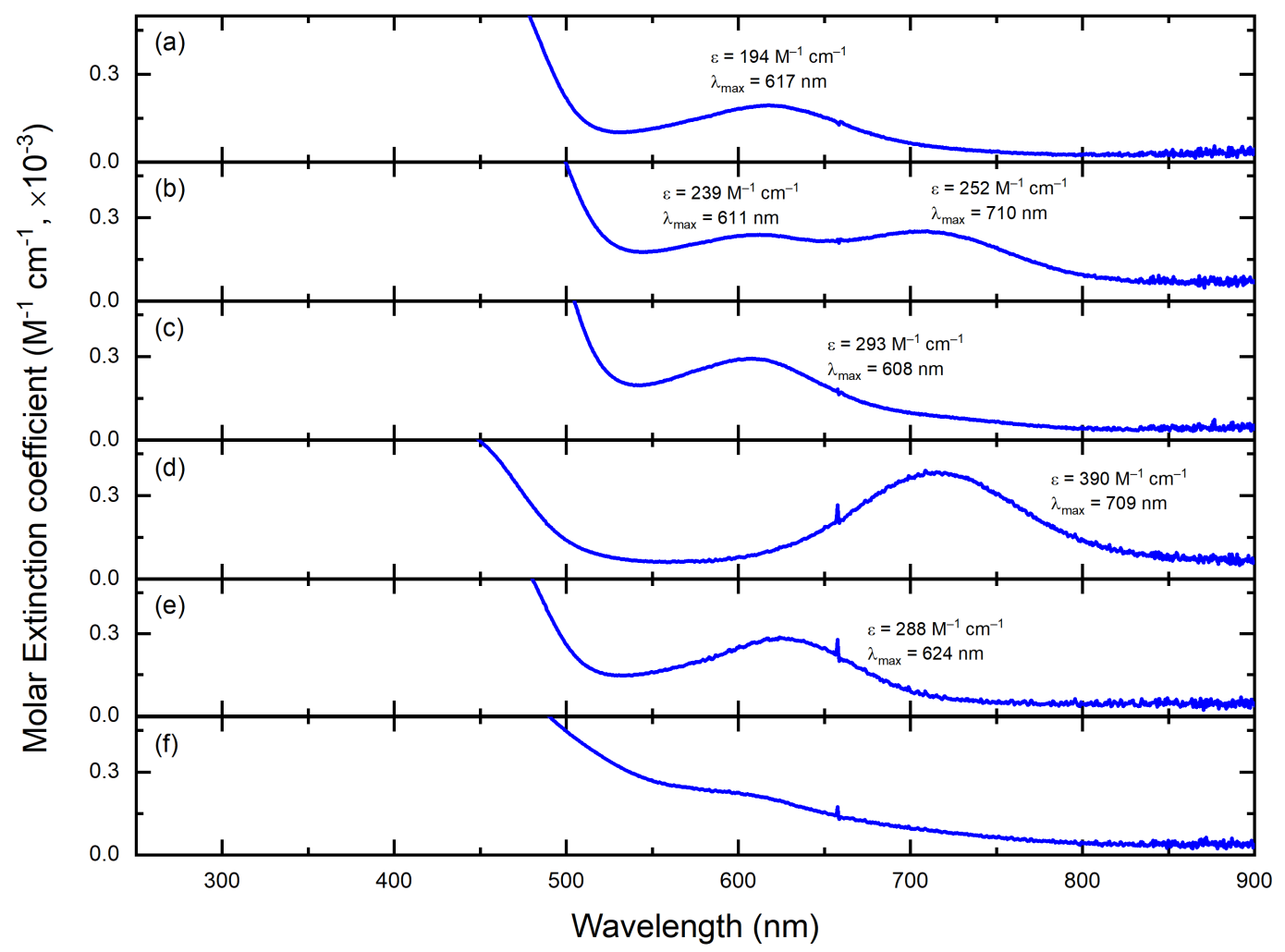

Figure S8. Electronic absorption spectra of 2 in (a) Pentane, (b) Benzene, (c) Toluene, (d) THF, (e) Hexane, (f) MeCN. 


\section{Electrochemistry}

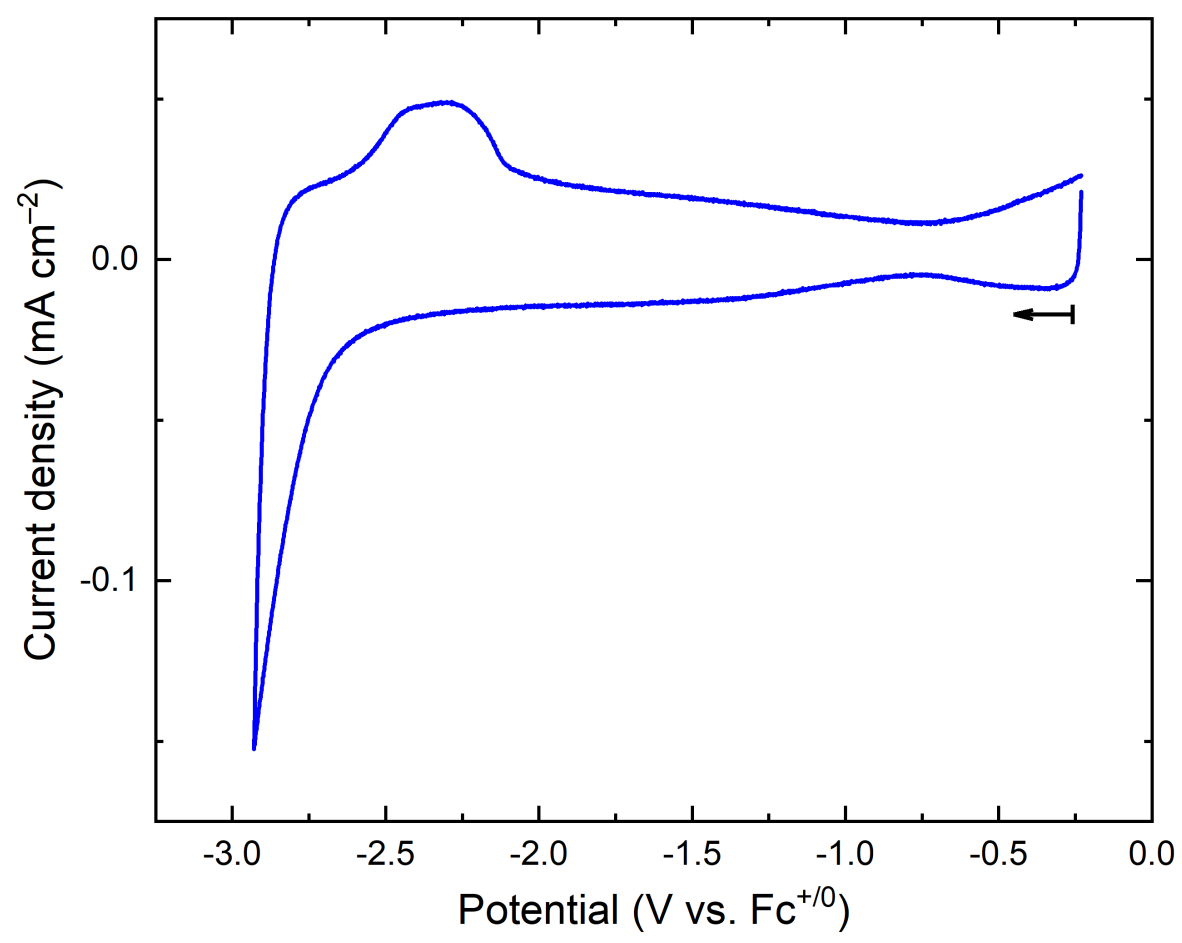

Figure S9. Cyclic voltammetry data for $\mathrm{AlEt}_{3}$ in $\operatorname{THF}\left(0.1 \mathrm{M}\left[{ }^{\mathrm{n}} \mathrm{Bu}_{4} \mathrm{~N}\right]^{+}\left[\mathrm{PF}_{6}\right]^{-}, 100 \mathrm{mV} / \mathrm{s}\right)$.

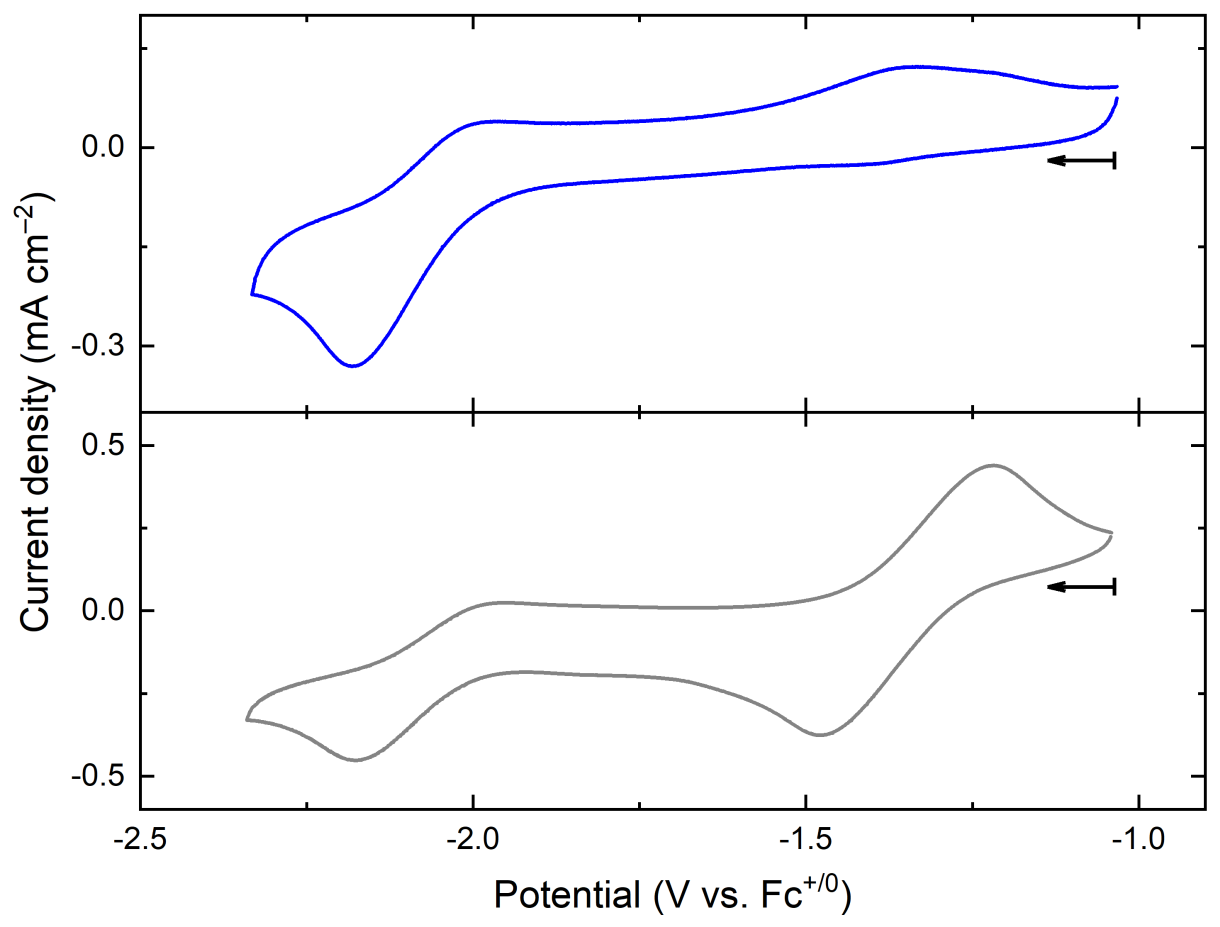

Figure S10. Cyclic voltammetry data for 4 (blue) and 4 in the presence of 1 equiv. of Cobaltocene (grey) in THF $\left(0.1 \mathrm{M}\left[{ }^{\mathrm{n}} \mathrm{Bu}_{4} \mathrm{~N}^{+}\left[\mathrm{PF}_{6}\right]^{-}, 100 \mathrm{mV} / \mathrm{s}\right)\right.$. 


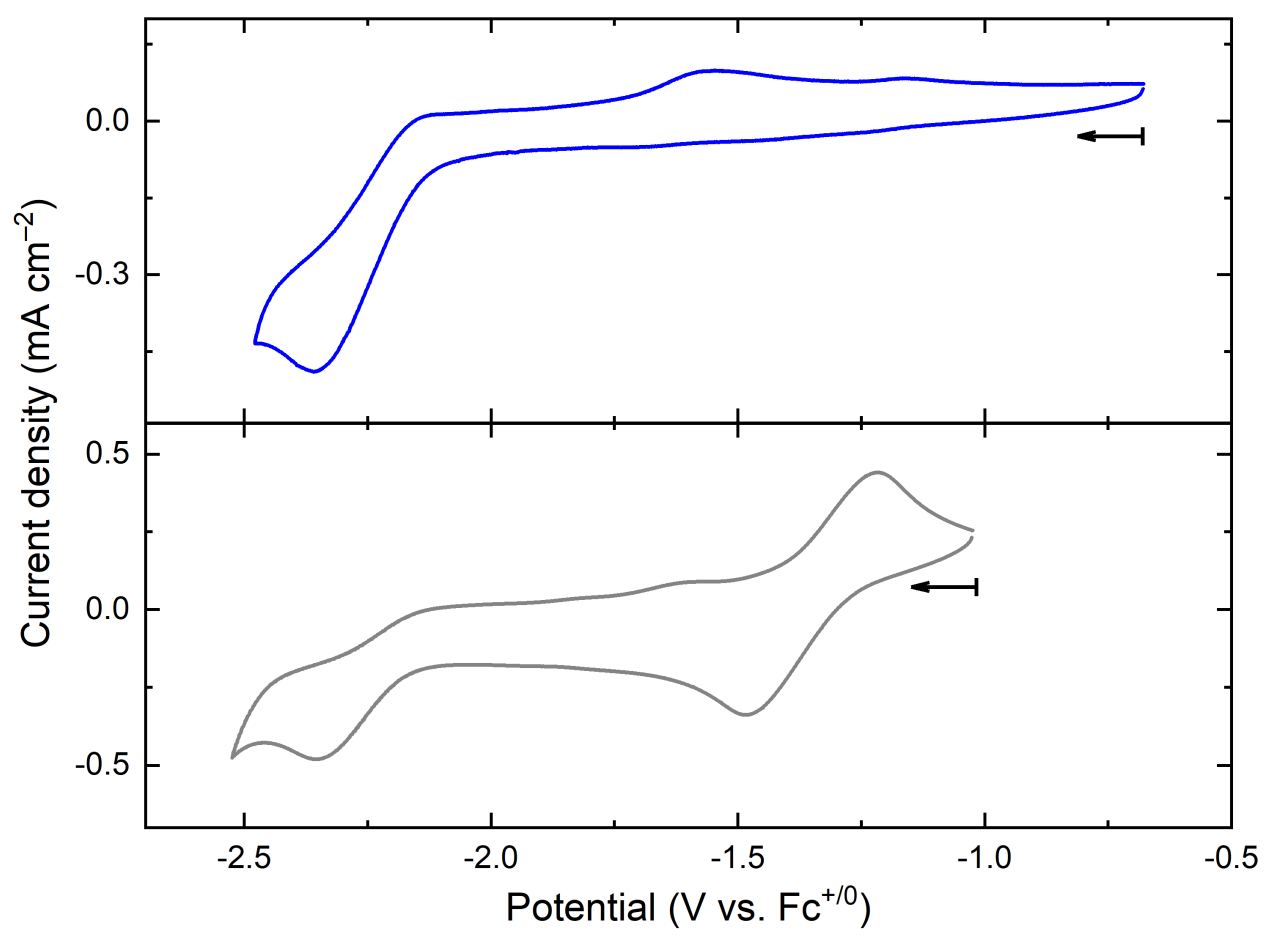

Figure S11. Cyclic voltammetry data for 5 (blue) and 5 in the presence of 1 equiv. of Cobaltocene (grey) in THF $\left(0.1 \mathrm{M}\left[{ }^{n} \mathrm{Bu}_{4} \mathrm{~N}^{+}\left[\mathrm{PF}_{6}\right]^{-}, 100 \mathrm{mV} / \mathrm{s}\right)\right.$.

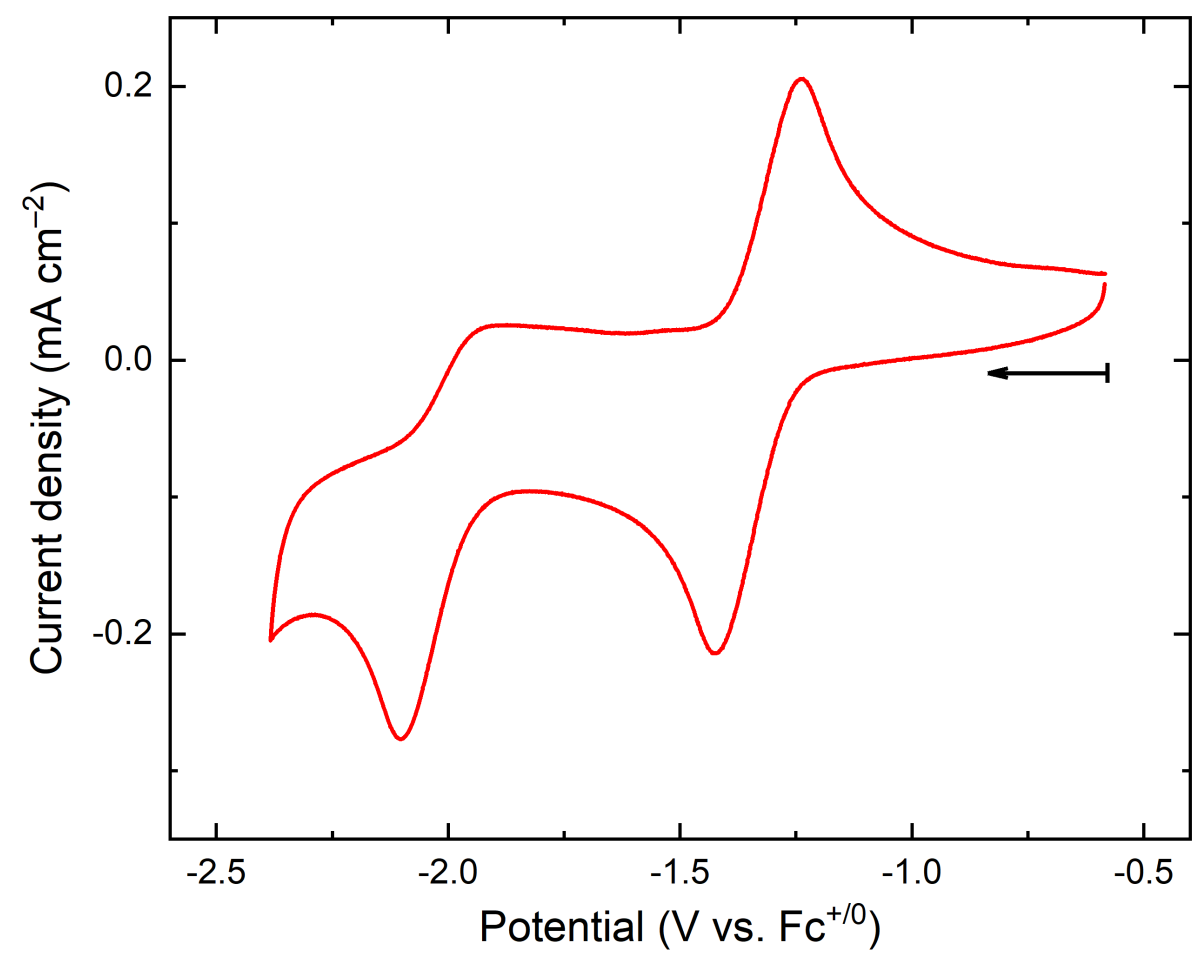

Figure S12. Cyclic voltammetry data for 1 in the presence of 1 equiv. of Cobaltocene in $\operatorname{THF}\left(0.1 \mathrm{M}\left[{ }^{\mathrm{n}} \mathrm{Bu} 4 \mathrm{~N}\right]^{+}\left[\mathrm{PF}_{6}\right]^{-}, 100 \mathrm{mV} / \mathrm{s}\right)$. 


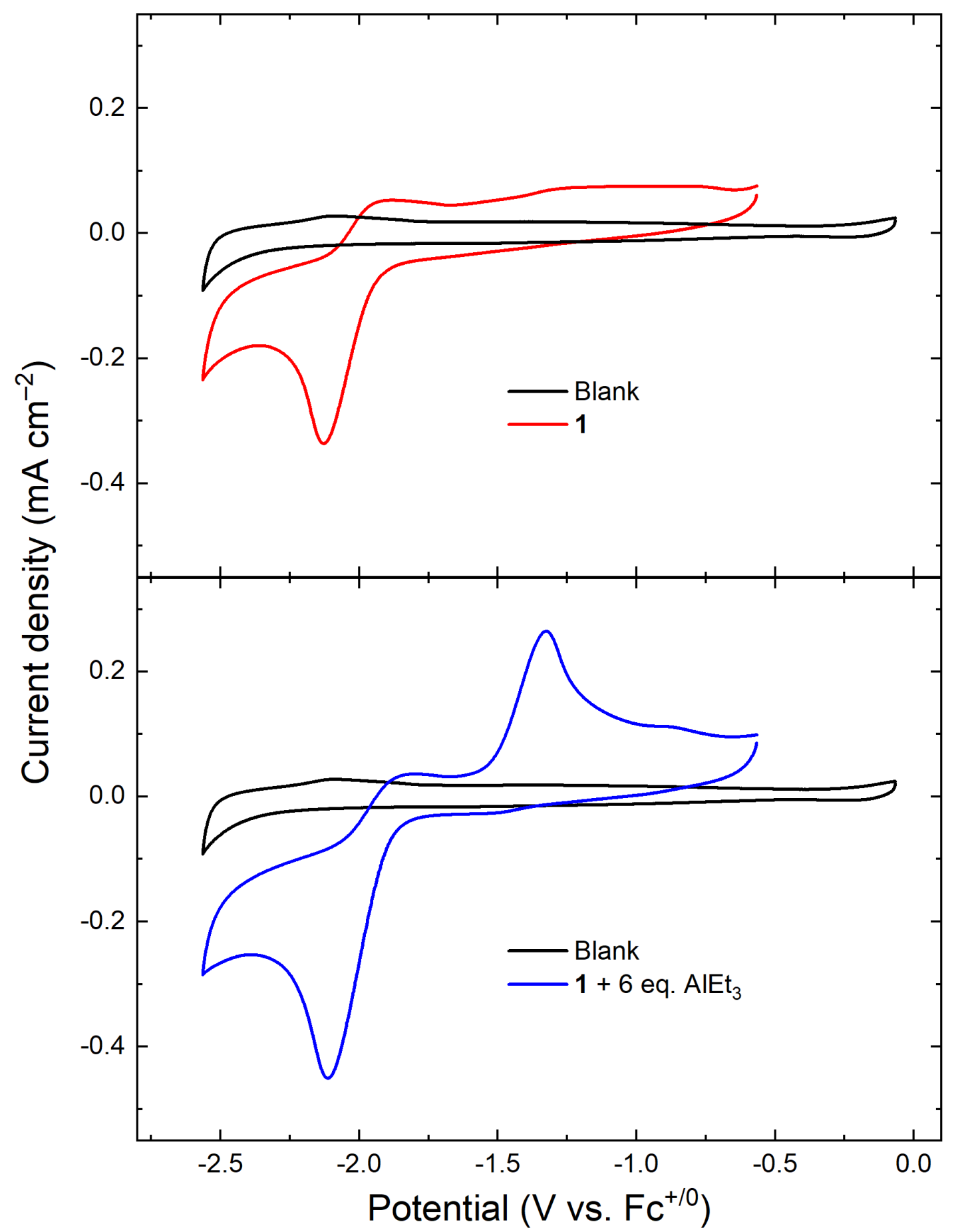

Figure S13. Cyclic Voltammetry Data for 1 (red) and $\mathbf{1}$ in the presence of AlEt 3 (blue) in $\operatorname{THF}\left(0.1 \mathrm{M}\left[{ }^{\mathrm{n}} \mathrm{Bu}_{4} \mathrm{~N}\right]^{+}\left[\mathrm{PF}_{6}\right]^{-}, 100 \mathrm{mV} / \mathrm{s}\right)$. 


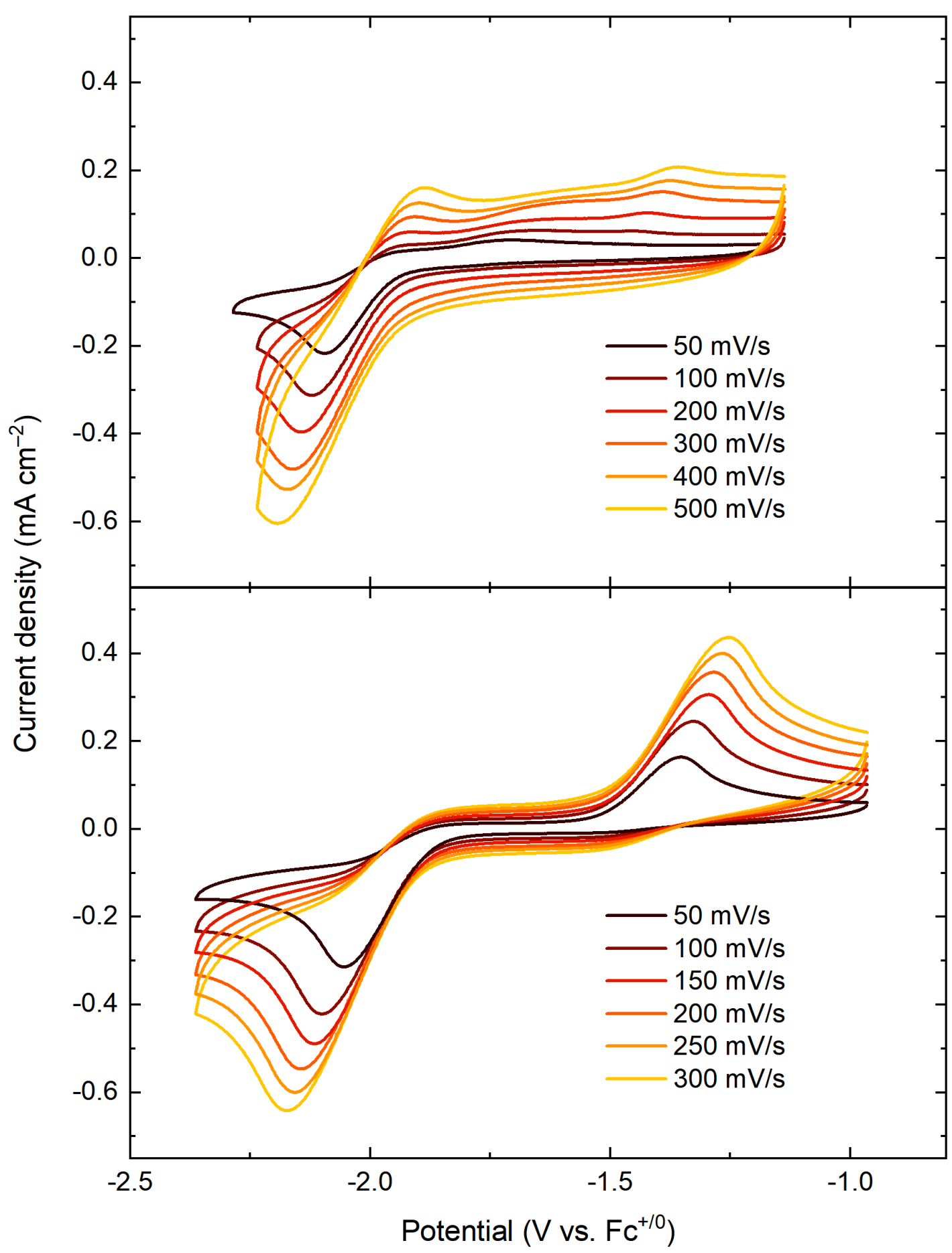

Figure S14. Cyclic voltammetry data for 1 (top) and 1 in the presence of $\mathrm{AlEt}_{3}$ (bottom) in THF at varying scan rates $\left(0.1 \mathrm{M}\left[{ }^{n} \mathrm{Bu}_{4} \mathrm{~N}\right]^{+}\left[\mathrm{PF}_{6}\right]^{-}\right)$. 


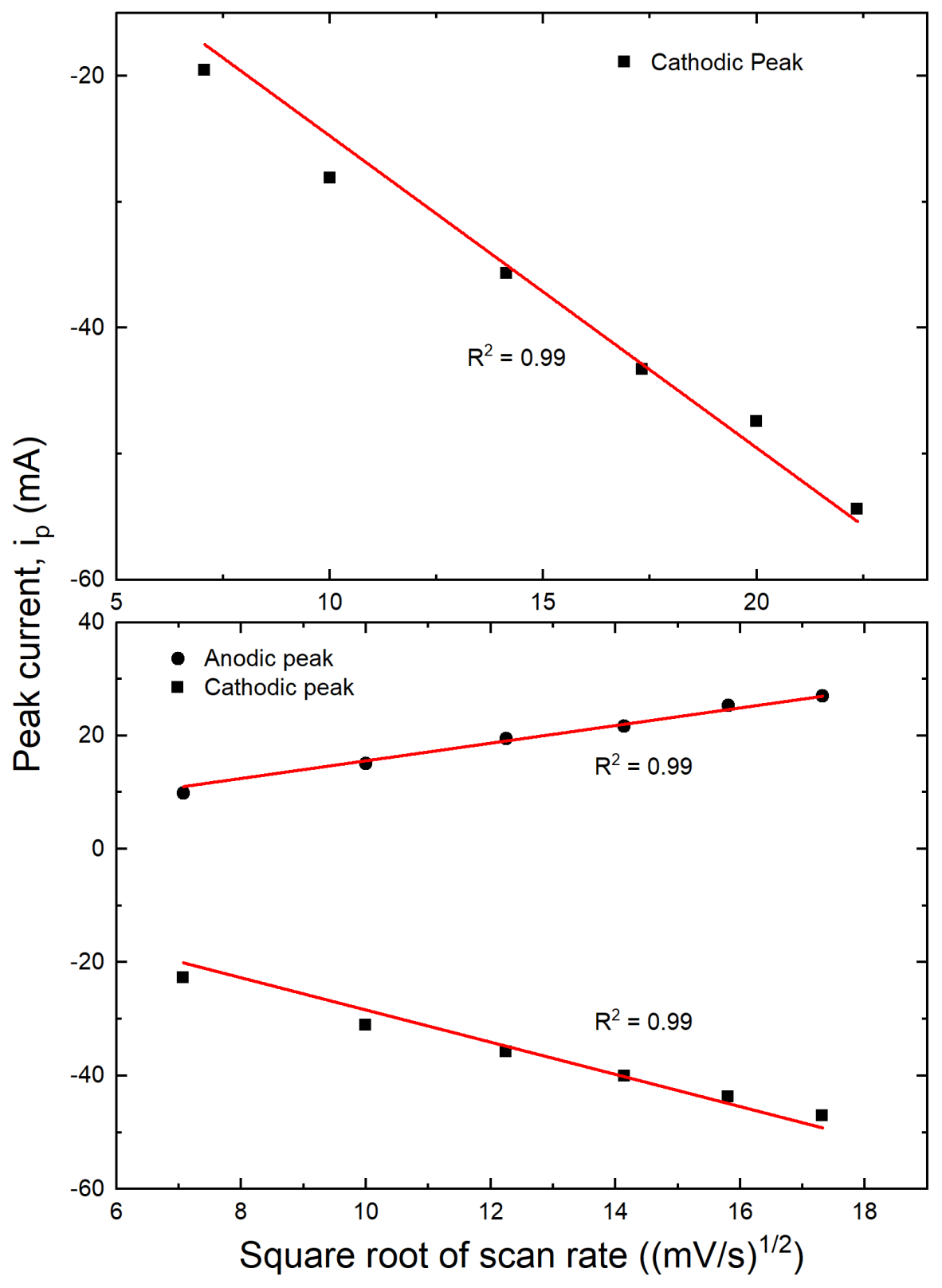

Figure S15. Linear dependence of peak current on square root of scan rate for 1 (top) and $\mathbf{1}$ in the presence of $\mathrm{AlEt}_{3}$ (bottom). 


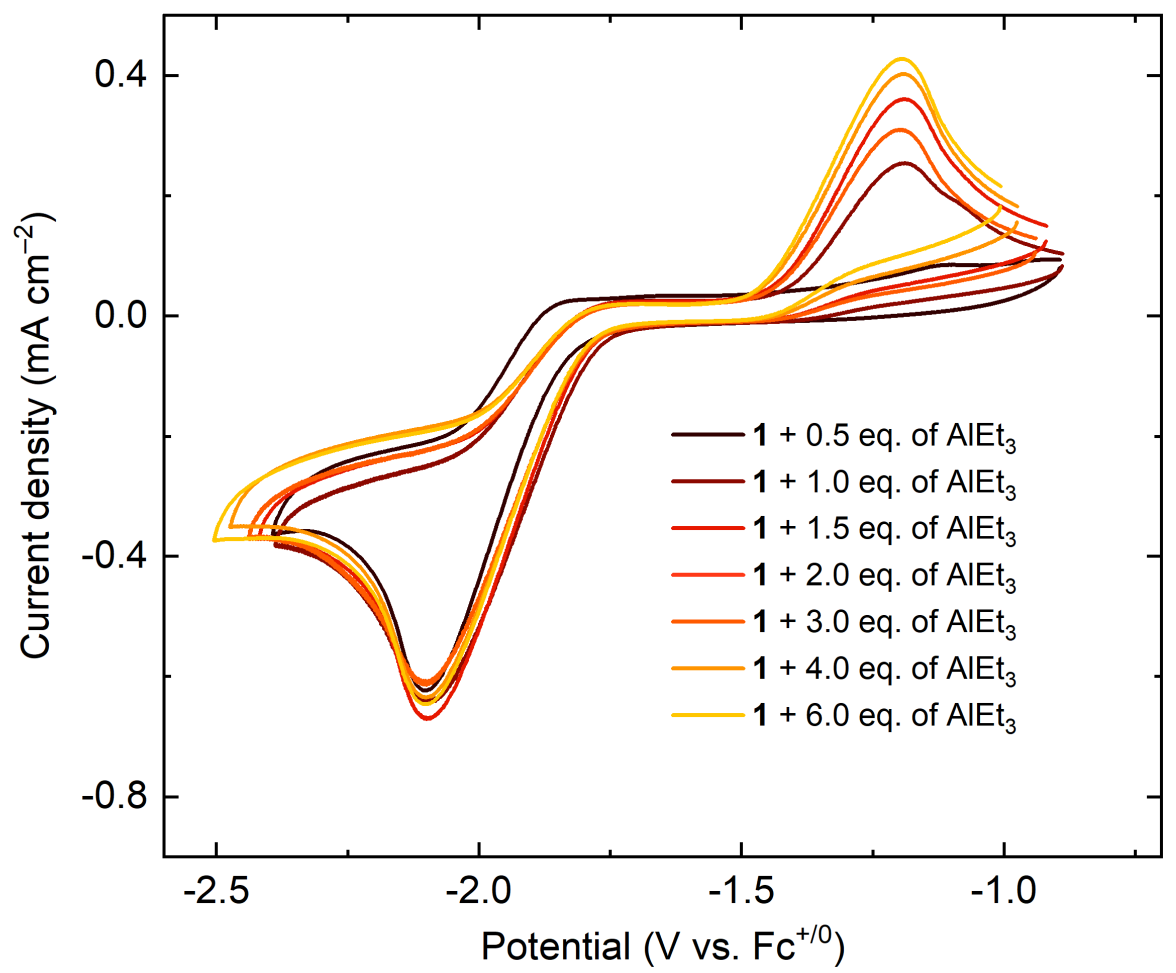

Figure S16. Electrochemical titration of 1 in the presence of increasing amounts of $\mathrm{AlEt}_{3}$ in $\operatorname{THF}\left(0.1 \mathrm{M}\left[{ }^{\mathrm{n}} \mathrm{Bu}_{4} \mathrm{~N}\right]^{+}\left[\mathrm{PF}_{6}\right]^{-}, 100 \mathrm{mV} / \mathrm{s}\right)$.

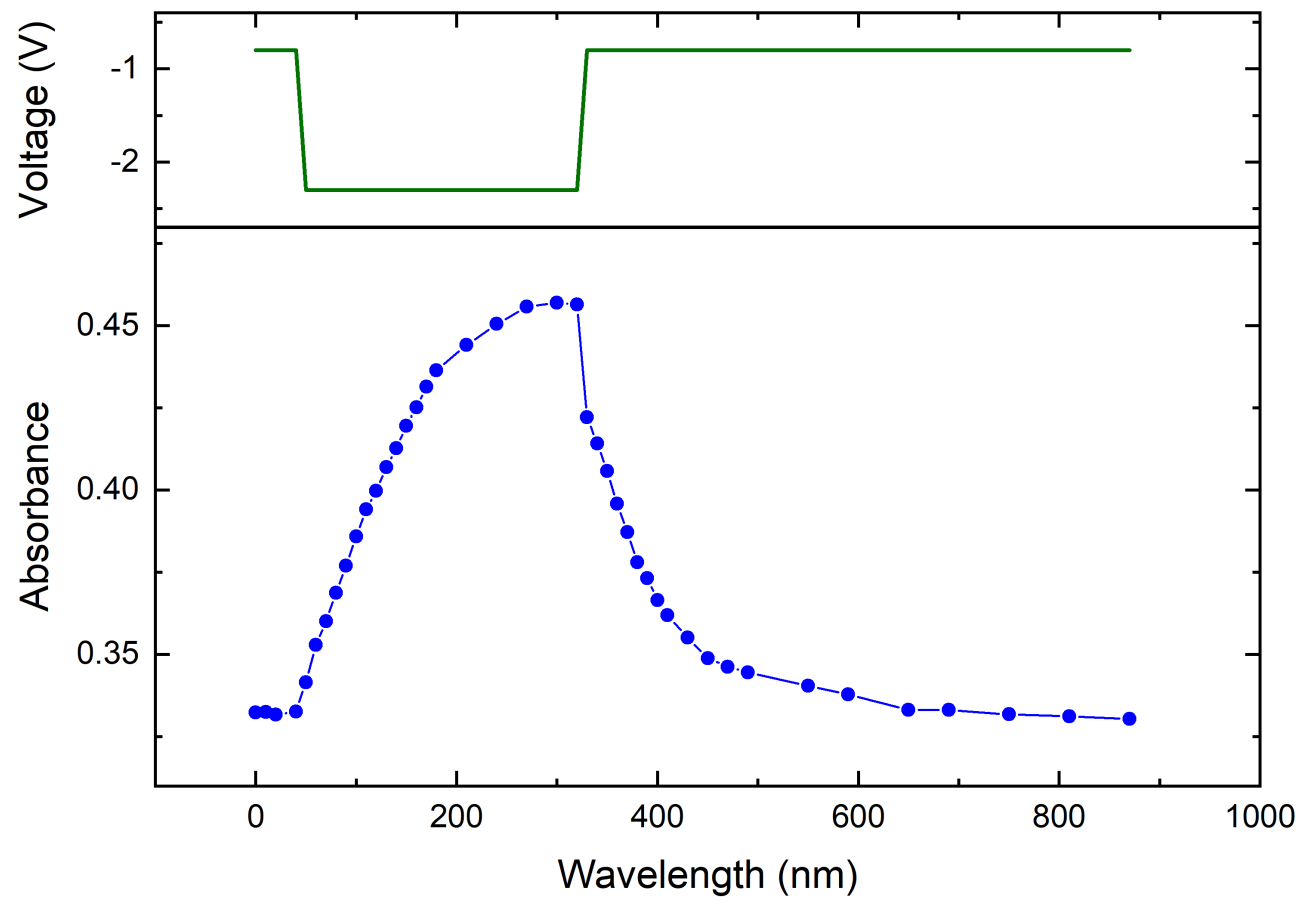

Figure S17. Spectroelectrochemical Data (Absorbance vs. Wavelength) for $\mathbf{1}$ in the presence of $\mathrm{AlEt}_{3}$ in $\operatorname{THF}\left(0.1 \mathrm{M}\left[{ }^{\mathrm{n}} \mathrm{Bu}_{4} \mathrm{~N}\right]^{+}\left[\mathrm{PF}_{6}\right]^{-}\right)$. 


\section{Gas Chromatography}

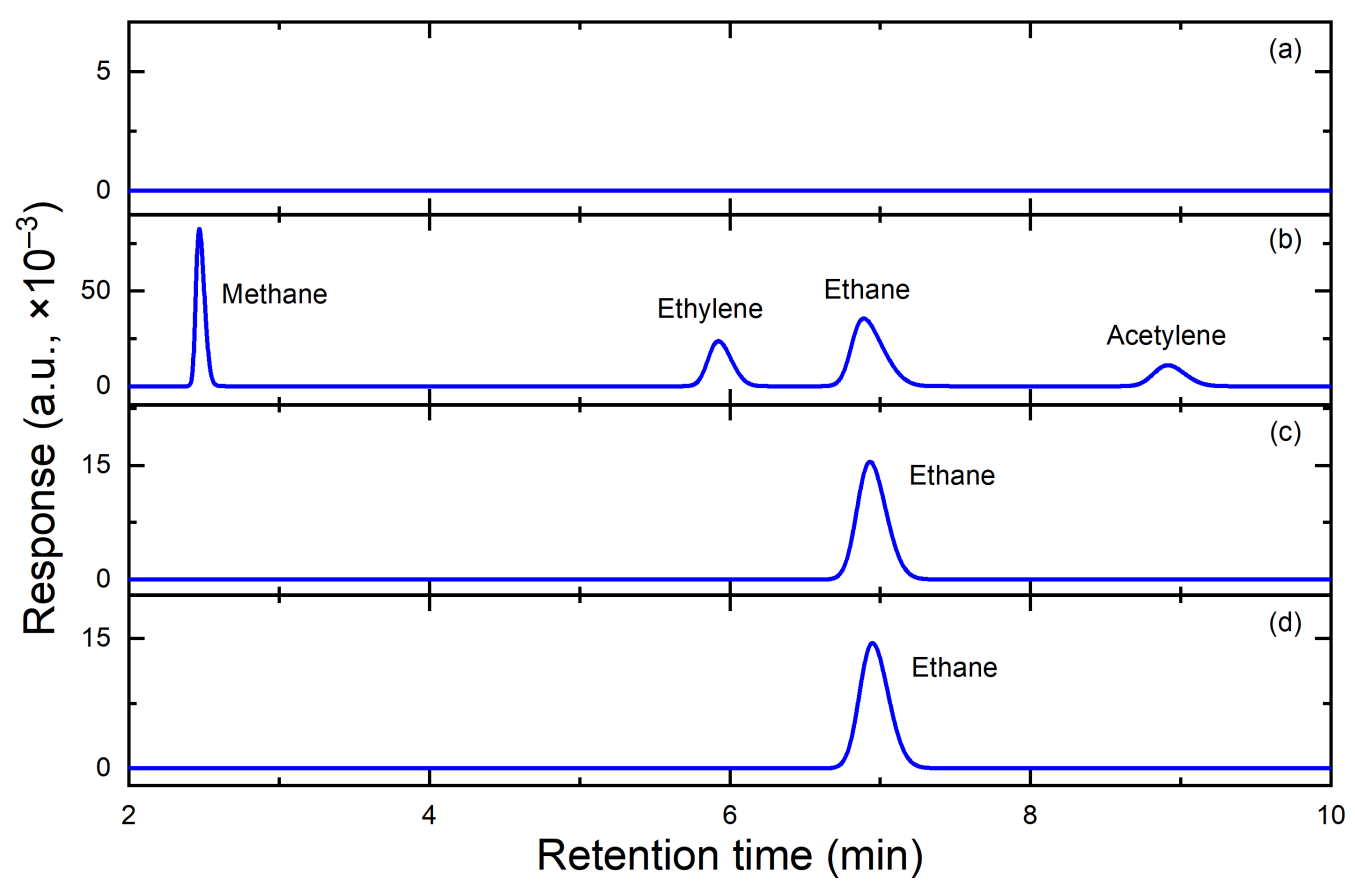

Figure S18. Gas Chromatography of 1 in the presence of $\mathrm{AlEt}_{3}$ during chemical reduction; (a) Blank, (b) Check Gas, (c) 1 with 2 equiv. of AlEt 3 in Benzene, (d) 1 with 2 equiv. of $\mathrm{AlEt}_{3}$ in Pentane.

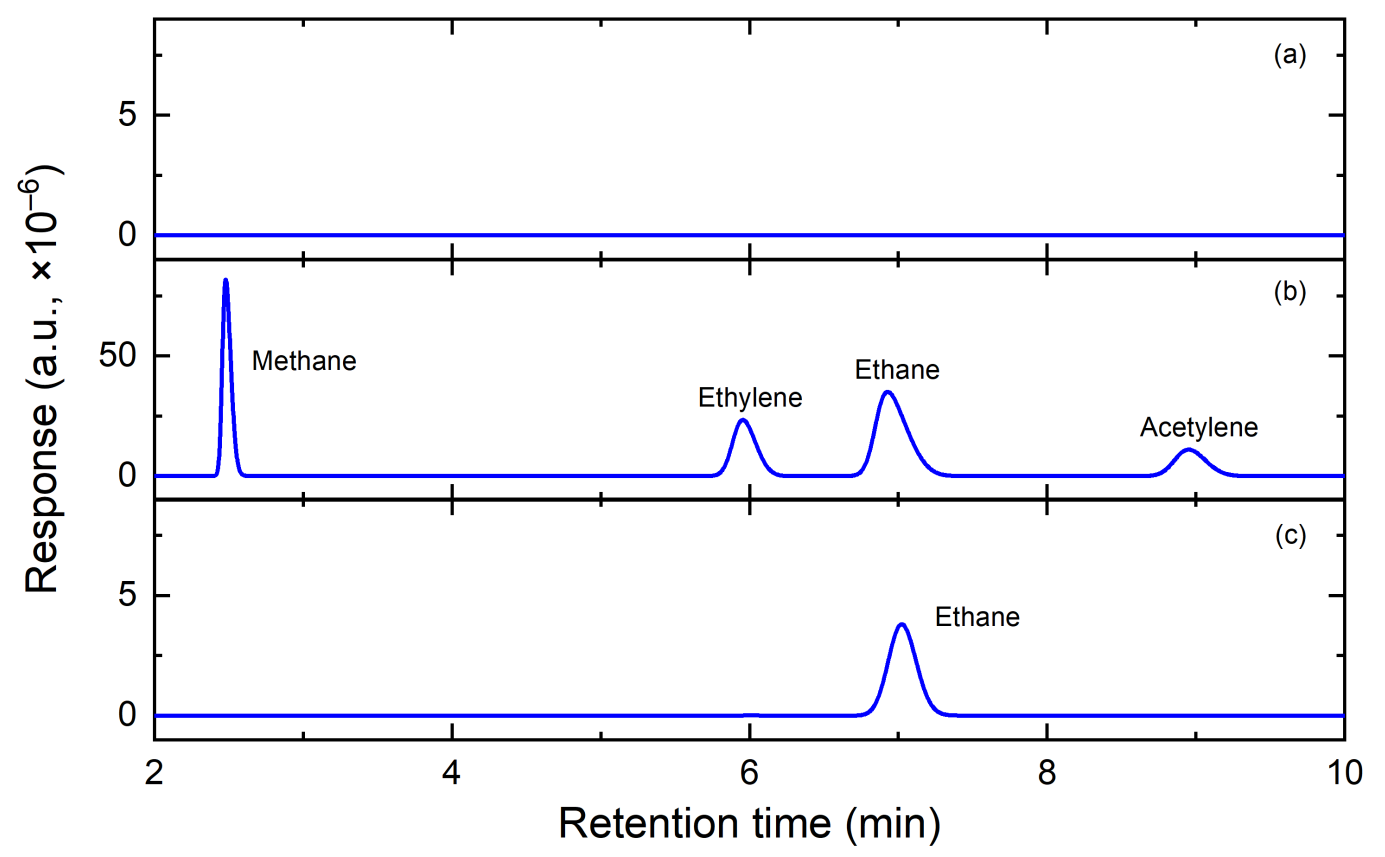

Figure S19. Gas Chromatography of 1 in the presence of $\mathrm{AlEt}_{3}$ during Bulk Electrolysis experiment; (a) Blank, (b) Check Gas, (c) 1 with 2 equiv. of AlEt 3 . Conditions: Electrolyte: $0.1 \mathrm{M}\left[\mathrm{nBu}_{4} \mathrm{~N}\right]^{+}\left[\mathrm{PF}_{6}\right]^{-}$in THF; Electrolysis Potential: $-2.4 \mathrm{~V}$; Time: 2 hours. 


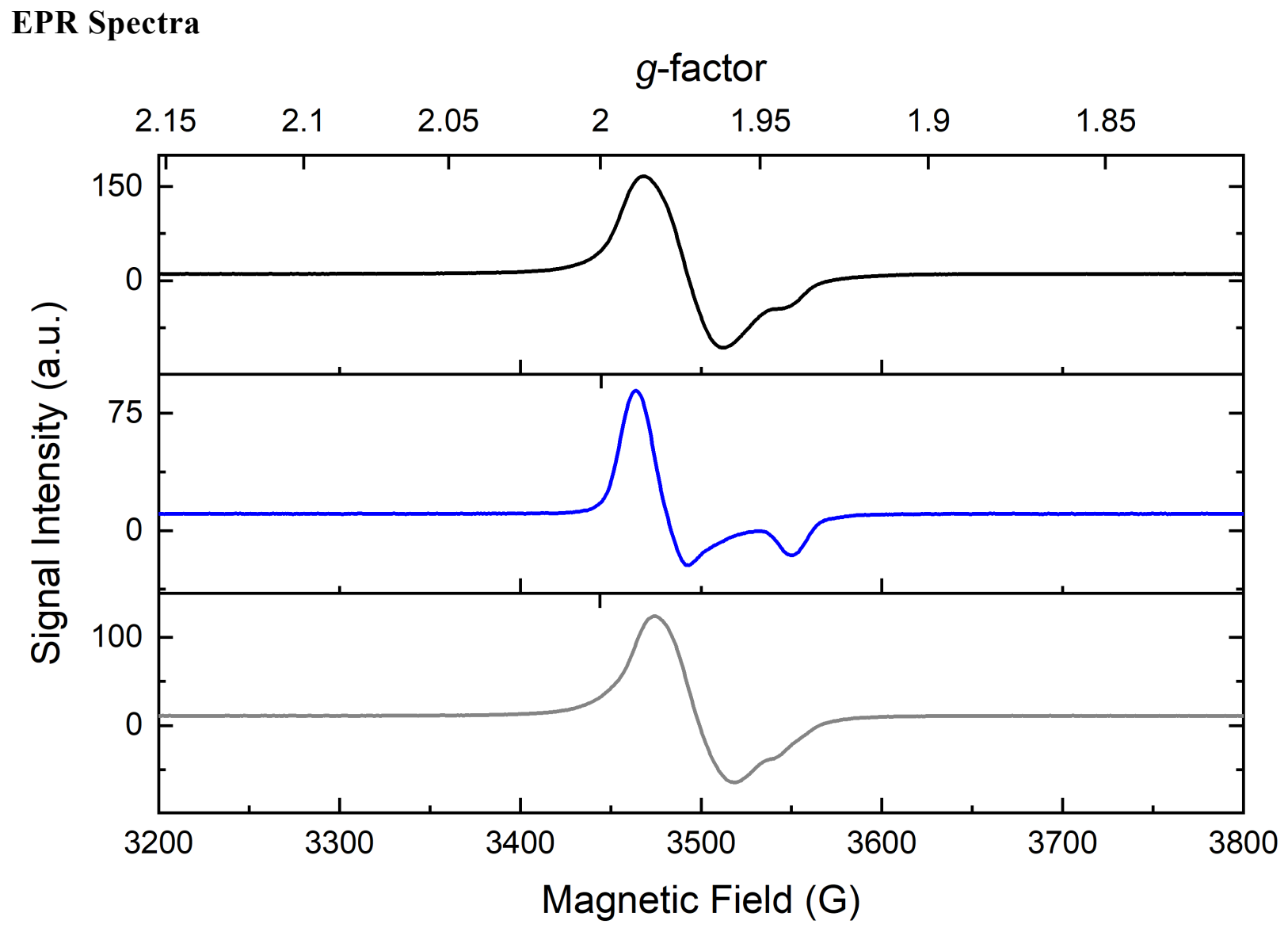

Figure S20. X-band CW EPR spectrum of 2 in hexane (black), toluene (blue) and THF (grey). 


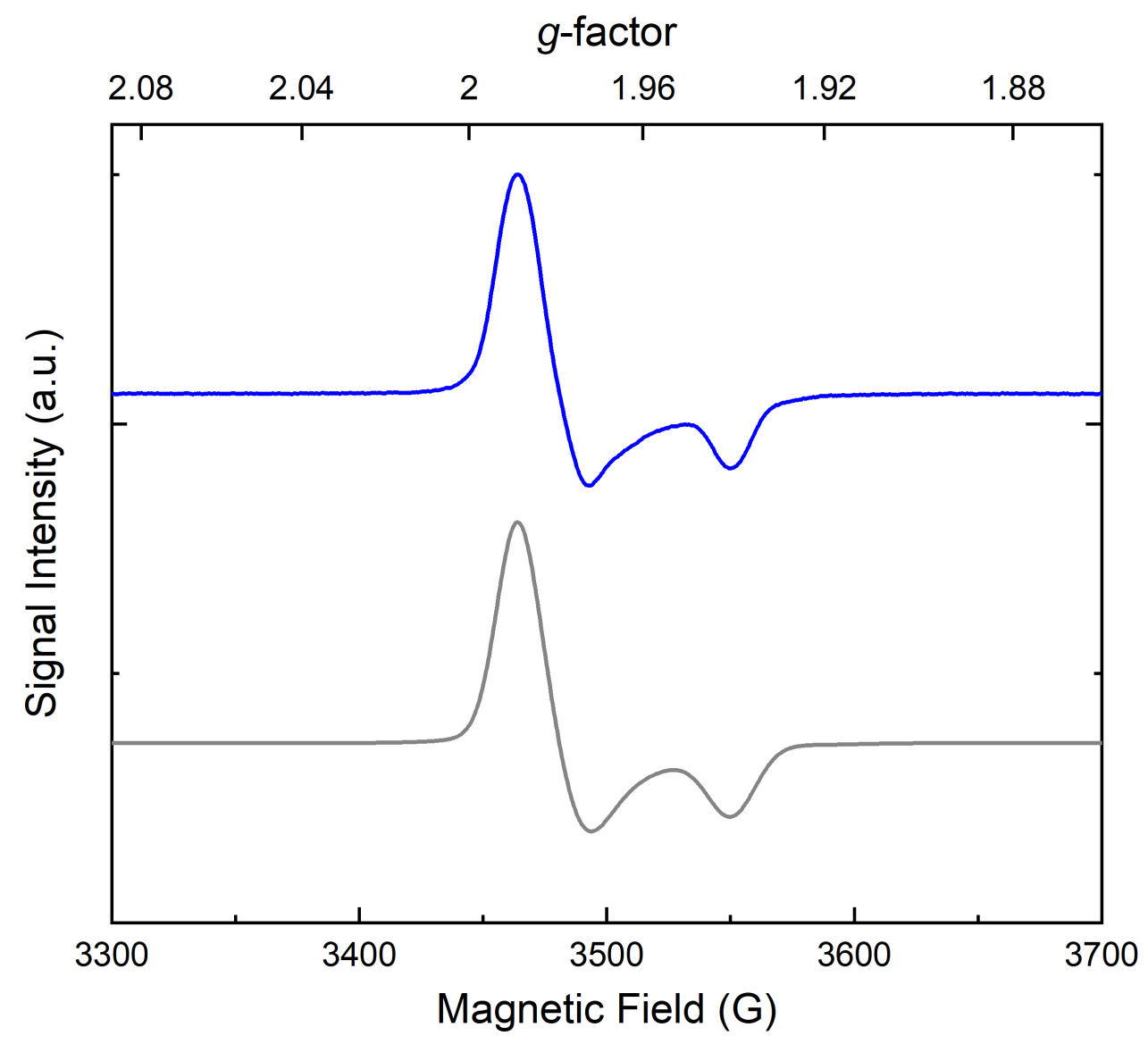

Figure S21. Blue: Electron paramagnetic resonance spectrum of 2 in frozen toluene at $55 \mathrm{~K}$ (Frequency: $9.6426 \mathrm{GHz}$; power: $0.032 \mathrm{~mW}$; time constant: $5 \mathrm{~ms}$; modulation amplitude: $4.0 \mathrm{G}$ ). Grey: Easyspin simulation of EPR data (simulation parameters: $\mathrm{S}=0.5 ; \mathrm{g}=[1.979$ 1.989 1.940]; nuclei: Ti; $A=$ [2 34 45]; HStrain = [65 49 60]; lw = 0.41).

\section{Mechanistic Pathway}

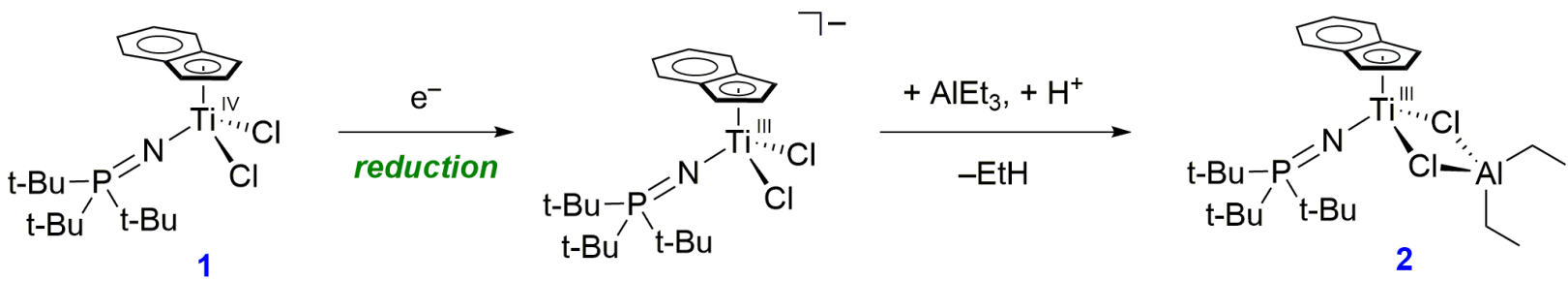

Figure S22. Electrochemical Pathway for the formation of $\mathbf{2}$ from $\mathbf{1 .}$ 


\section{X-Ray Crystallography}

The single crystal X-ray diffraction studies were carried out on a Bruker APEX-II ULTA CCD diffractometer equipped with Mo K $_{\alpha}$ radiation $(\lambda=0.71073 \AA)$.

\section{$\left[(\right.$ Ind $\left.)\left(t \mathrm{Bu}_{3} \mathrm{P}=\mathbf{N}\right) \mathrm{TiCl}_{2}\right](\mathbf{1})$}

Crystals of the subject compound were used as received (grown from toluene layered with hexane, $-30^{\circ} \mathrm{C}$ ). A $0.220 \times 0.220 \times 0.180 \mathrm{~mm}$ green block crystal was mounted on a Cryoloop with Paratone oil. Data were collected in a nitrogen gas stream at 100(2) K using $\varphi$ and $\omega$ scans. Crystal-to-detector distance was $55 \mathrm{~mm}$ and exposure time was 15.0 seconds per frame using a scan width of $0.60^{\circ}$. Data collection was $95.7 \%$ complete to $25.00^{\circ}$ in $\theta$. A total of 10969 reflections were collected covering the indices, $-14<=\mathrm{h}<=14,-14<=\mathrm{k}<=14$, $18<=1<=11.12455$ reflections were found to be symmetry independent, with a $R_{\text {int }}$ of 0.0524. Indexing and unit cell refinement indicated a primitive, triclinic lattice. The space group was found to be $P-1$. The data were integrated using the Bruker SAINT Software program $^{4}$ and scaled using the SADABS 5 software program. Solution by direct methods $\left(\right.$ SHELXT) ${ }^{6}$ produced a complete phasing model consistent with the proposed structure. All nonhydrogen atoms were refined anisotropically by full-matrix least-squares using Olex software package (SHELXL-2014).$^{7-8}$ All carbon bonded hydrogen atoms were placed using a riding model. Their positions were constrained relative to their parent atom using the appropriate HFIX command in SHELXL-2014. Crystallographic data are summarized in Table S1. Note: Twin data, used HKL 5 format for final refinement. RIGU instruction applied.

\section{$\left[(\right.$ Ind $\left.)\left(t \mathrm{Bu} u_{3} \mathrm{P}=\mathrm{N}\right) \mathbf{T i}\left(\mu_{2}-\mathrm{Cl}_{2}\right)_{2} \mathrm{AlEt}_{2}\right\rfloor(2)$}

Crystals of the subject compound were used as received (grown from hexane, $-30^{\circ} \mathrm{C}$ ). A $0.220 \times 0.175 \times 0.130 \mathrm{~mm}$ irregular piece of green crystal was mounted on a Cryoloop with Paratone oil. Data were collected in a nitrogen gas stream at 100(2) K using $\varphi$ and $\omega$ scans. Crystal-to-detector distance was $45 \mathrm{~mm}$ and exposure time was 7 seconds per frame using a scan width of $1.00^{\circ}$. Data collection was $99.9 \%$ complete to $25.00^{\circ}$ in $\theta$. A total of 31728 reflections were collected covering the indices, $-13<=\mathrm{h}<=13,-23<=\mathrm{k}<=18,-30<=1<=29$. 5024 reflections were found to be symmetry independent, with a $\mathrm{R}_{\mathrm{int}}$ of 0.1027 . Indexing and unit cell refinement indicated a primitive, orthorhombic lattice. The space group was found to be $P$ bca. The data were integrated using the Bruker SAINT software program ${ }^{4}$ and scaled using the SADABS 5 software program. Solution by direct methods (SHELXT) ${ }^{6}$ produced a complete phasing model consistent with the proposed structure. All nonhydrogen atoms were refined anisotropically by full-matrix least-squares using Olex software package (SHELXL-2014) ${ }^{6-7}$ All carbon bonded hydrogen atoms were placed using a riding model. Their positions were constrained relative to their parent atom using the appropriate HFIX command in SHELXL-2014. Crystallographic data are summarized in Table S1. Note: Minor twin component, best refinement "ignoring" the twin and integrating as a single component. 
Table S1. Crystal and Refinement Data for 1 and 2.

\begin{tabular}{|c|c|c|}
\hline & 1 & 2 \\
\hline CCDC number & 1900171 & 1900172 \\
\hline Empirical formula & $\mathrm{C}_{21} \mathrm{H}_{34} \mathrm{Cl}_{2} \mathrm{NPTi}$ & $\mathrm{C}_{25} \mathrm{H}_{44} \mathrm{AlCl}_{2} \mathrm{NPTi}$ \\
\hline Formula weight & 450.26 & 535.36 \\
\hline Temperature & 100.0 & 100.0 \\
\hline Wavelength & 0.71073 & 0.71073 \\
\hline Crystal system & triclinic & orthorhombic \\
\hline Space group & P-1 & $\mathrm{Pbca}$ \\
\hline$a$ & $12.354(2) \AA$ & $11.3833(16) \AA$ \\
\hline$b$ & $12.438(2) \AA$ & $19.759(3) \AA$ \\
\hline$c$ & $15.637(3) \AA$ & $25.362(3) \AA$ \\
\hline$a$ & $84.468(3)$ & 90 \\
\hline $\boldsymbol{\beta}$ & $89.960(3)$ & 90 \\
\hline$\gamma$ & $76.272(2)$ & 90 \\
\hline Volume & $2322.7(6) \AA^{3}$ & $5704.4(14) \AA^{3}$ \\
\hline $\mathbf{Z}$ & 4 & 8 \\
\hline Density (calculated) & $1.288 \mathrm{~g} / \mathrm{cm}^{3}$ & $1.247 \mathrm{~g} / \mathrm{cm}^{3}$ \\
\hline Absorption coefficient & $0.673 \mathrm{~mm}^{-1}$ & $0.588 \mathrm{~mm}^{-1}$ \\
\hline $\mathbf{F}(000)$ & 952.0 & 2280.0 \\
\hline Crystal size & $0.22 \times 0.22 \times 0.18 \mathrm{~mm}^{3}$ & $0.22 \times 0.175 \times 0.13 \mathrm{~mm}^{3}$ \\
\hline Theta range & 3.388 to 50.762 & 4.424 to 50 \\
\hline Index ranges & $\begin{array}{c}-14 \leq \mathrm{h} \leq 14,-14 \leq \mathrm{k} \leq 14,-18 \\
\leq 1 \leq 12\end{array}$ & $\begin{array}{c}-13 \leq \mathrm{h} \leq 13,-23 \leq \mathrm{k} \leq 18,-30 \\
\leq 1 \leq 29\end{array}$ \\
\hline Reflections collected & 15464 & 31728 \\
\hline Independent reflections & $\begin{array}{c}15464\left[\mathrm{R}_{\text {int }}=0.0524, \mathrm{R}_{\text {sigma }}=\right. \\
0.1055]\end{array}$ & $\begin{array}{c}5024\left[R_{\text {int }}=0.1027, R_{\text {sigma }}=\right. \\
0.0703]\end{array}$ \\
\hline Absorption correction & Multi-scan & Multi-scan \\
\hline Refinement method & Full-matrix least-squares on $\mathrm{F}^{2}$ & Full-matrix least-squares on $\mathrm{F}^{2}$ \\
\hline Data/restraints/parameters & $10969 / 156 / 488$ & $5024 / 0 / 291$ \\
\hline Goodness-of-fit on $\mathbf{F}^{2}$ & 1.006 & 1.061 \\
\hline Final $R$ indices $[I>2 \sigma(I)]$ & $\mathrm{R}_{1}=0.0605, \mathrm{wR}_{2}=0.1276$ & $\mathrm{R}_{1}=0.0673, \mathrm{wR}_{2}=0.1426$ \\
\hline$R$ indices (all data) & $\mathrm{R}_{1}=0.1105, \mathrm{wR}_{2}=0.1471$ & $\mathrm{R}_{1}=0.0965, \mathrm{wR}_{2}=0.1546$ \\
\hline Largest diff. peak \& hole & 0.60 and $-0.61 \mathrm{e}^{-} / \AA^{3}$ & 0.73 and $-0.50 \mathrm{e}^{-} / \AA^{3}$ \\
\hline
\end{tabular}

${ }^{a} R 1 \Sigma|| F_{o}|-| F_{c}|| / \Sigma\left|F_{o}\right| \quad{ }^{b} w R 2=\left[\Sigma\left[w\left(F_{o}^{2}-F_{c}^{2}\right)^{2}\right] / \Sigma\left[w\left(F_{o}^{2}\right)^{2}\right]\right]^{1 / 2}$ 
Table S2. Comparison of Select Bond Lengths (Å).

\begin{tabular}{ccc}
\hline Bonds & $\mathbf{1}$ & $\mathbf{2}$ \\
\hline Ti-N & $1.729(5)$ & $1.797(4)$ \\
Ti-Cl & $2.288(2), 2.310(2)$ & $2.532(1), 2.521(1)$ \\
P=N & $1.622(5)$ & $1.589(4)$ \\
Ti-C ind & $2.360(6)-2.545(7)$ & $2.304(5)-2.509(4)$
\end{tabular}

Table S3. Comparison of Select Bond Angles ( $\left.{ }^{\circ}\right)$.

\begin{tabular}{ccc}
\hline Angles & $\mathbf{1}$ & $\mathbf{2}$ \\
\hline P-N-Ti & $172.5(3)$ & $175.9(2)$ \\
Cl-Ti-Cl & $103.6(1)$ & $81.5(1)$ \\
Cl-Ti-N & $102.0(2), 103.2(2)$ & $102.7(1), 106.0(1)$ \\
Cl-Al-Cl & - & $93.8(1)$ \\
Al-Cl-Ti & - & $92.2(1), 92.4(1)$
\end{tabular}

\section{References}

1. (a) Stephan, D. W.; Stewart, J. C.; Guérin, F.; Spence, R. E. v. H.; Xu, W.; Harrison, D. G. Organometallics 1999, 18, 1116. (b) Guerin, F.; Beddie, C. L.; Stephan, D. W.; Spence, R. E. V. H.; Wurz, R., $\eta^{1}$ - and $\eta^{5}$-indenyl and cyclopentadienyl tri-tert-butylphosphoraneiminato titanium complexes. Organometallics 2001, 20, 3466-3471.

2. McDaniel, M. P.; Collins, K. S.; Johnson, M. M.; Smith, J. L.; Benham, E. A.; Hawley, G. R.; Wittner, C. E.; Jensen, M. D. US6107230A, 2000.

3. McDaniel, M. P.; Collins, K. S.; Johnson, M. M.; Smith, J. L.; Benham, E. A.; Halwey, G. R.;. Wittner, C. E.; Jensen, M. D. US6316553B1, 2001.

4. SAINT. Ver. 8.34A. Bruker Analytical X-ray Systems: Madison, WI, June 2014.

5. Sheldrick, G. M., SADABS (version 2008/1): Program for Absorption Correction for Data from Area Detector Frames, University of Göttingen, 2008.

6. Sheldrick, G., Acta Crystallogr., Sect. A: Found. Crystallogr. 2015, 71, 3-8.

7. Sheldrick, G. Acta Crystallogr., Sect. C: Cryst. Struct. Commun. 2015, 71, 3-8.

8. Dolomanov, O. V.; Bourhis, L. J.; Gildea, R. J.; Howard, J. A. K.; Puschmann, H. J. Appl. Crystallogr. 2009, 42, 339-341. 